This PDF is a selection from a published volume from the National Bureau of Economic Research

Volume Title: Seeking a Premier Economy: The Economic Effects of British Economic Reforms, 1980-2000

Volume Author/Editor: David Card, Richard Blundell and Richard B. Freeman, editors

Volume Publisher: University of Chicago Press

Volume ISBN: 0-226-09284-4

Volume URL: http://www.nber.org/books/card04-1

Conference Date: December 8-9, 2000

Publication Date: June 2004

Title: Has 'In-Work' Benefit Reform Helped the Labor Market?

Author: Richard Blundell, Hilary W. Hoynes

URL: http://www.nber.org/chapters/c6753 


\title{
Has "In-Work" Benefit Reform Helped the Labor Market?
}

\author{
Richard Blundell and Hilary Hoynes
}

\subsection{Introduction}

Welfare policy toward low-income families in the United Kingdom experienced a significant shift toward "in-work" benefits in the late 1980s and 1990s. Although a work requirement for some forms of benefit receipt has existed in the United Kingdom since the late 1970s, the shift in policy began in earnest with the introduction of the Family Credit (FC) in 1988-a minimum-working-hours-based credit for families with children. After a number of reforms during the early 1990s, FC was replaced by the Working Families Tax Credit (WFTC) in 1999. Over this period the generosity of these "in-work" benefit schemes also increased, enhancing the emphasis that has been placed in welfare reform on supplementing low incomes in work for adults with dependent children (see Blundell 2002). As of 2000, there are over 1 million recipients, contrasting with less than 250,000 when FC was introduced. Expenditure per recipient has also increased dramatically over this period, rising fourfold in real terms.

But what of the impact on the labor market? There have been two main target groups for in-work benefit policy reform in the United Kingdom.

Richard Blundell is the Leverhulme Research Professor at University College London, director of the Economic and Social Research Council (ESRC) Centre for the Microeconomic Analysis of Public Policy and research director, both at the Institute for Fiscal Studies (IFS). Hilary Hoynes is associate professor of economics at the University of California, Davis, and a research associate of the National Bureau of Economic Research.

We have benefited from the comments and advice of participants at the conference meetings, two anonymous referees, and especially Mike Brewer, David Card, Alan Duncan, Costas Meghir, and Michal Myck. We are also very grateful to Mike Brewer, Darren Lubotsky, and Zoe Smith for generous help in preparing and interpreting the figures and tables. The research is part of the program of the ESRC Centre for the Microeconomic Analysis of Fiscal Policy at IFS. 
These target groups reflect a rise in the proportion of families with no parent working in the 1980s and early 1990s. For single parents and lowskilled couples with children, labor market attachment steadfastly refused to rise after the sharp fall in the early 1980 s recession - quite against the overall trend. Single parent employment rates fell by 20 percentage points in the early 1980s and have remained well below that experienced by many of the United Kingdom's European neighbors. For women with unemployed husbands, the fall in employment was even more marked, remaining at little over 20 percent. Over the same period the overall trend for married mothers saw a continuing growth, and employment among single women without children remained around the 80 percent level. For the United States the picture is quite different. The early 1980s decline in employment was short lived and was followed by a 14 percentage point increase in the 1990s. For couples with children in the United States, there was a steady increase in employment for both parents. The behavior of these different groups in the United Kingdom and the differences in employment trends with similar groups in the United States presents us with a puzzle. This is the focus of this study.

The comparison with the U.S. system of in-work benefits is particularly useful. Like the system in the United Kingdom, the Earned Income Tax Credit (EITC) in the United States has grown significantly in terms of coverage and generosity over the past two decades. As of 1999, it has seen a fourfold increase in caseload, and expenditure per recipient has tripled in real terms. It is now the largest cash program directed toward working families in the United States, with nearly 20 million recipients. Not only are the United States and the United Kingdom similar in being at the forefront of the use of in-work benefits, but the two nations' other socioeconomic profiles also bear interesting similarities. The proportion of single parents in the United States and the United Kingdom more than doubled over the past two decades-one reason why this group featured so centrally in the policy agenda. Moreover, single parents in both countries began the period, the late 1970s, with very similar employment rates, close to those of married women with children. Both countries experienced a similar rise in employment rates of married women with children. The real contrast is the gain in employment for single parents in the United States and the higher employment rates among low-skilled couples with children.

Although the administration of the system in the United States is somewhat different from that in the United Kingdom, we do not attribute the apparent differences in impact on labor supply to this. Instead, we highlight certain distinct features of the U.K. system. First, unlike the EITC, income from in-work benefits is counted as income in the computation of other benefits - in particular, housing benefits. This is shown to significantly dampen the labor supply incentives created by the in-work benefit system. The importance of housing benefits has increased strongly since 
the early 1980s in the United Kingdom. Second, over the same period much of the increase in the generosity of in-work benefits has been matched by increases in the generosity of income support-available to low-income nonworking families with children. In particular, increases in child credits in the in-work benefit system have been matched by similar increases in the generosity in the child component of income support. There has also been a substantive increase in the real value of the universal child benefit. If anything, these increases act as an income effect and against increased employment in the target groups. Again this contrasts importantly with the United States, where there has been a relative decline in the value of outof-work income supports.

The remainder of the paper is organized as follows. In the next section, the underlying labor market trends are presented. Section 10.3 describes the reforms in the United Kingdom and their impact on work incentives. Section 10.4 draws a direct comparison with the impact of EITC reforms in the United States. In section 10.5 we evaluate the recent WFTC reform in the United Kingdom. Section 10.6 concludes.

\subsection{Trends in Labor Supply over the 1980s and 1990s}

Although differences in the pattern of working behavior across different groups at any point in time can be suggestive of important impacts of financial incentives, it is the time series behavior of labor supply for groups of individuals who have been subject to changing incentives that is of direct policy interest. This is precisely the way the puzzle in the introduction was posed between the employment behavior of single mothers in the United Kingdom and the United States.

In this section we focus on trends in the United Kingdom over the last two decades but also draw on evidence from the United States where comparisons are particularly informative. One well-documented trend that occurred in both countries over this period is the shift in returns to education and skill. We do not reproduce them here, but they have certainly reinforced the arguments for increasing the generosity of in-work benefits for low-income workers' families.

Macroeconomic conditions over the past two decades differed somewhat in the United States and United Kingdom. There are two large recessions in the United Kingdom, one in 1980-1981 and one in 1991-1993. The recession in the United States in the early 1990 s was shorter and less severe. For the remainder of the 1990s the United States experienced an unprecedented expansion, with unemployment rates lower than they had been in three decades. The expansion in the United Kingdom occurred much later and at a slower pace. It is likely that the differences in the strength of the labor markets across the two countries explain some of the difference in the employment trends discussed here. This may be especially important for 
low-education groups, who are typically found to be more sensitive to business cycles (Hoynes 2000).

\subsubsection{Overall Employment Trends for Women}

To describe these trends we draw on a number of data sets from the United Kingdom and the United States. These are briefly described in the data appendix. Figure 10.1 shows the fraction of women working in the United Kingdom by marital status and presence of children from 1978 to 1999. Figure 10.2 shows a similar contrast for the United States. We have selected women aged between twenty and fifty-five for this comparison.

There are many similarities in employment for women in the United Kingdom and the United States over this time period. First, single parents have very similar employment rates at the beginning of the period, at about 55 to 60 percent. These are close to those for married women with children. Second, the labor market attachment for married women, especially those with children, saw a steady rise over the period in both countries. For example, in the United States, somewhat less than one-half of married women with children worked at all in 1979 , compared to almost 70 percent in 2000. Third, single women without children experienced a rather more stable and higher level of employment, at around 80 percent, over these two decades in both countries.

The differences between the United Kingdom and United States, however, are striking. First, the employment for all groups was more severely

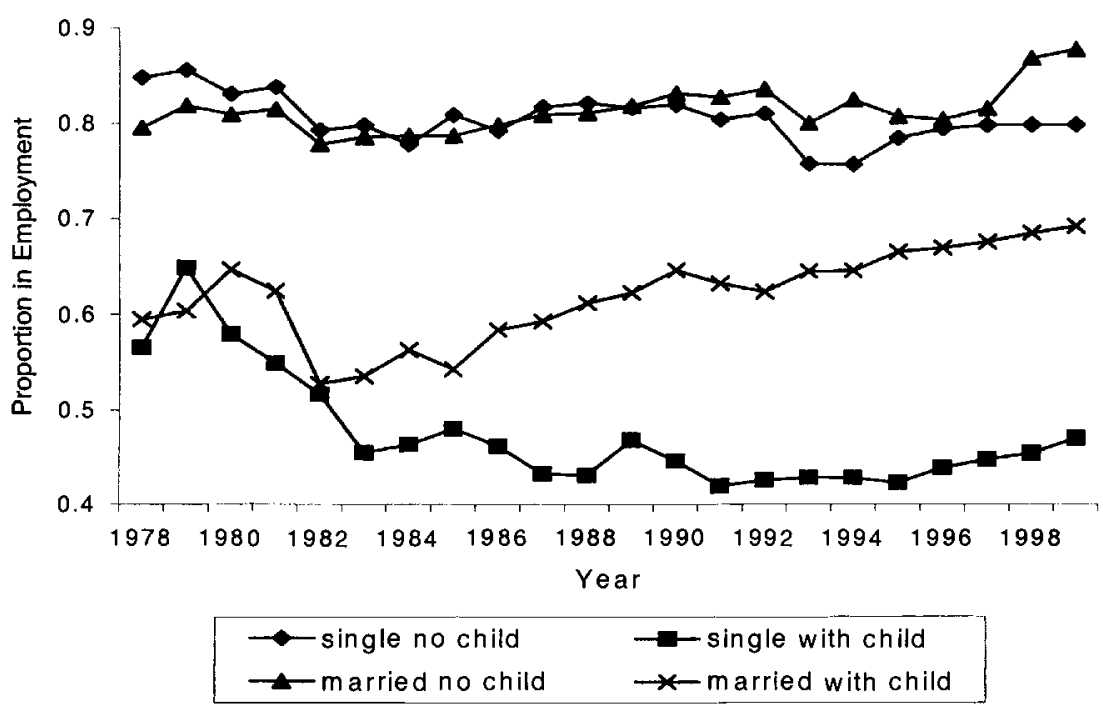

Fig. 10.1 Employment trends for women in the United Kingdom Source: U.K. FES data. 


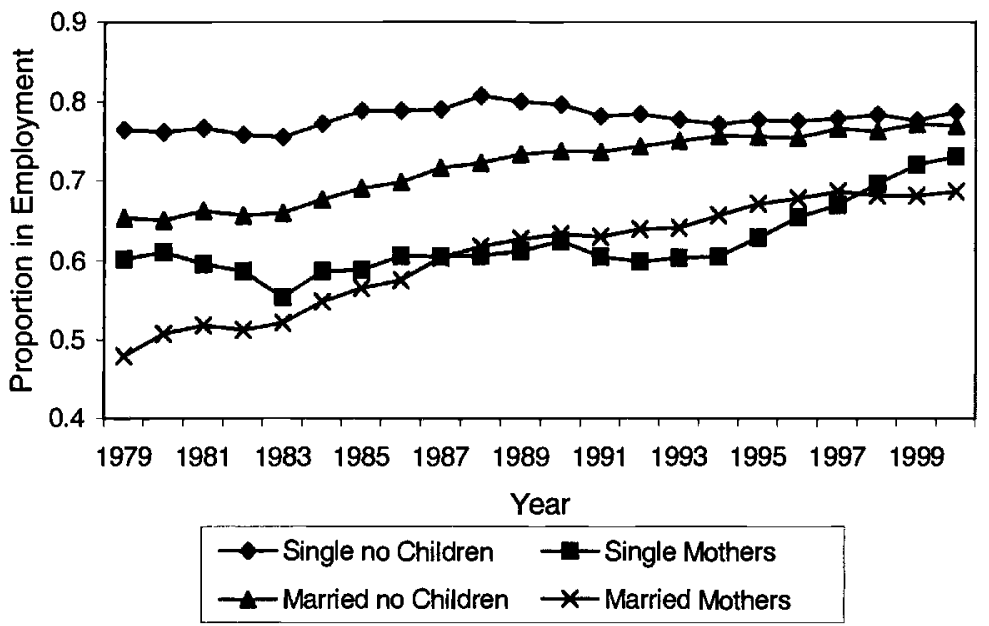

Fig. 10.2 Employment trends for women in the United States Source: U.S. March CPS data.

reduced in the United Kingdom during the recession in the early 1980s. Second, single mothers in the United Kingdom saw little recovery from the initial decline in employment in the early 1980s. In the United States, beginning in the early 1990s, employment in this group increased dramatically, from 60 to 73 percent. ${ }^{1}$ Married women saw steady increases in work over this period. The increase in employment among single women with children in the United States is not due to a cohort effect. When the employment trends are presented by cohort, the increase in employment is shared by all but the oldest age groups. In fact, among less-educated women the gains are largest for the youngest cohort.

\subsubsection{A Focus on Single Mothers}

In-work benefit reform will provide the greatest incentives for those individuals who can only attract a low market wage. One way to focus on this "incentivized" group is to consider those with lower levels of schooling. Figures 10.3 and 10.4 consider the pattern of employment by education for single mothers in the United Kingdom and United States, respectively. In both the United Kingdom and the United States, single women were an increasing share of all women over this period. In contrast, the fraction of women who are married with children is declining steadily over this period.

1. The U.S. definition of work is "working at all last week," which is chosen to be comparable to the U.K. definition of "employment in the past two weeks." An additional measure that may capture better the intensity of work is the average number of weeks worked last year. In figures not shown here, the trends for the average weeks worked show much the same pattern as those for "worked at all last week." 


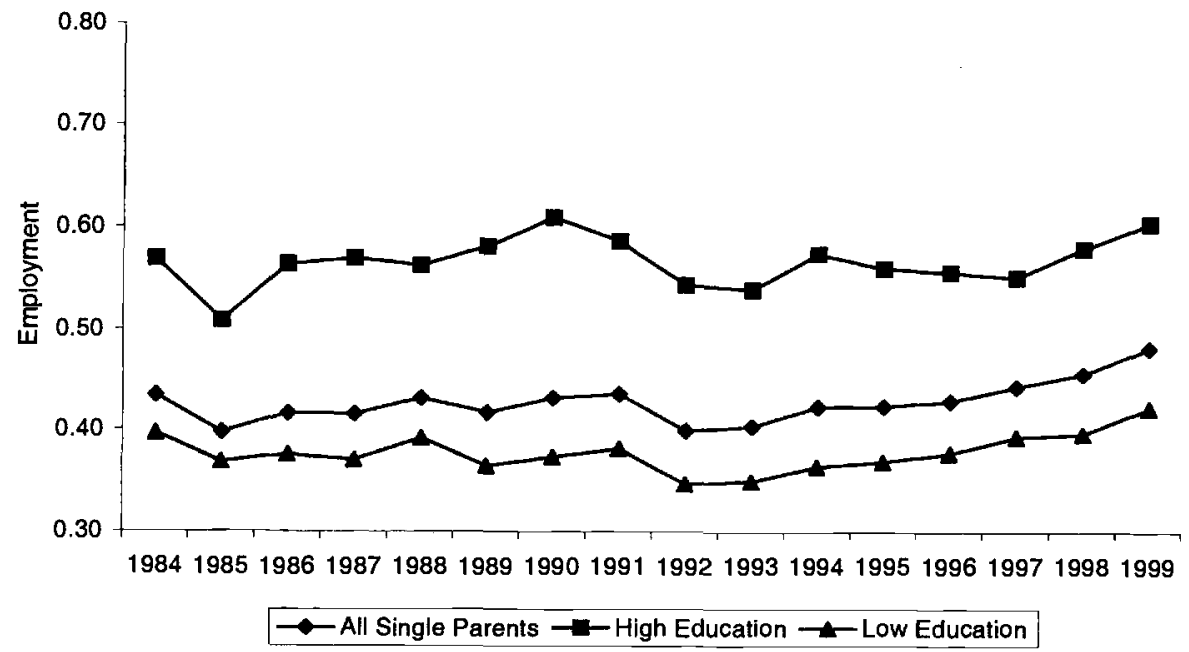

Fig. 10.3 Employment trends for single mothers by education in the United Kingdom

Source: U.K. LFS data.

Note: Low education "left school at age 16 or below."

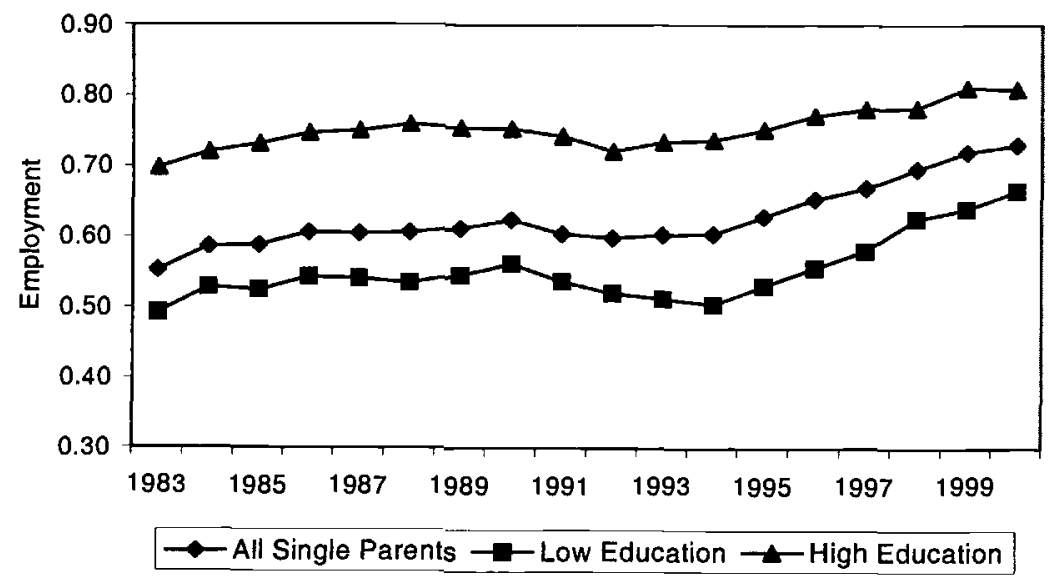

Fig. 10.4 Employment trends for single mothers by education in the United States Source: U.S. March CPS data.

Note: Low education "left school at twelfth grade or below." 
Single women with children represent an increasing fraction of all women, especially among less-educated women. By the end of the 1990s this group represented nearly one-fifth of all low-educated working-age women in the United Kingdom, up from around 6 percent at the turn of the 1980s.

These trends for low-educated single parents are presented for the period since 1984. This period is primarily chosen so that the larger Labour Force Survey can be utilized for the United Kingdom, but it also coincides with the period over which most of the action on in-work benefit reforms has taken place.

The differences between the employment patterns for women in the United Kingdom versus the United States presented previously are also evident here. In the United Kingdom the employment pattern for the lowereducated single mothers, those who left school at age sixteen (the minimum school-leaving age), is very similar to the picture for all single mothers. The employment rate for lower-education single mothers remained quite low throughout the period. In contrast, in the United States the employment rate of lower-educated single women with children increased from 50 percent in 1994 to almost 67 percent in 2000, a gain of more than 16 percentage points. Indeed, in the United States, by the end of the period, loweducated single women with children were working more than married women with children, and almost as much as single women without children. This increase has received tremendous attention in the United States and is the subject of some debate as to how much of this can be attributed to policy versus the strong economy.

One additional feature of the U.K. data for single women that will be important for the discussion of in-work benefit reform is the distribution of hours of work. As will be discussed, since 1992 the U.K. system has provided a strong incentive for single mothers to work at least sixteen hours per week. The frequency histogram for low-education single women with and without children in the United Kingdom over three recent years is presented in figure 10.5. The peak at sixteen hours for single mothers is clear.

\subsubsection{Workless Couples with Children}

The in-work benefit reforms in the United Kingdom have targeted both single parents and workless couples. Figure 10.6 shows the growing importance of this latter group in the United Kingdom toward the end of the 1980 s and the early 1990s. In the 1980s recession, the percentage of married couples with children without an earner increased substantially.

Figure 10.6 shows that, similar to the pattern for single mothers, this rate has not declined much in the subsequent period. This pattern is not found in the United States, however. Like the increase in employment among single women with children, the fraction of married couples without any work has been in decline. In fact, even among low-educated couples, the 
Single Mothers, low education $1997 / 98$

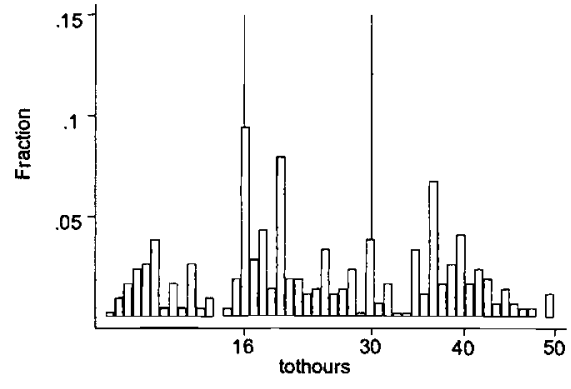

Single no children, low education $1997 / 98$

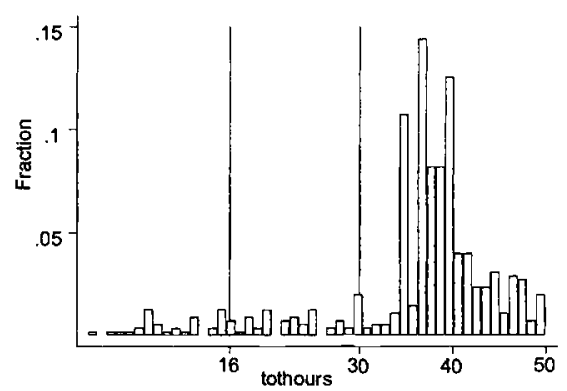

$1998 / 99$

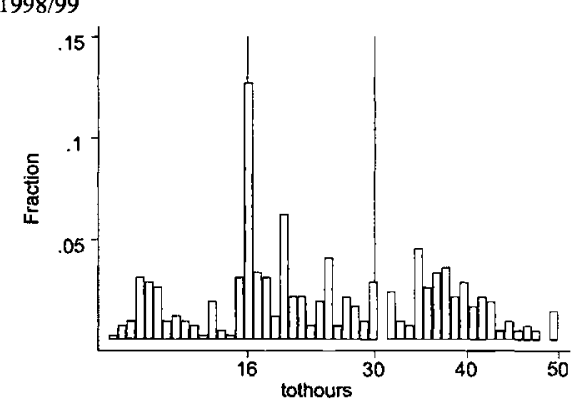

$1999 / 00$

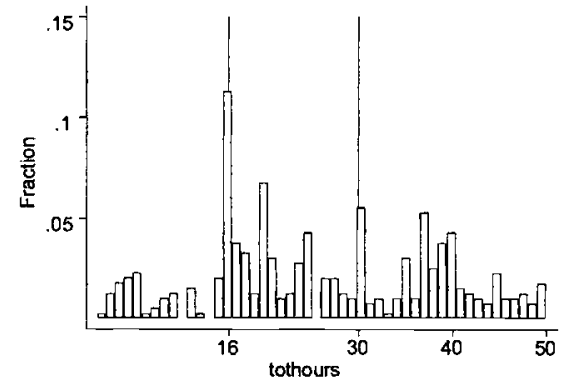

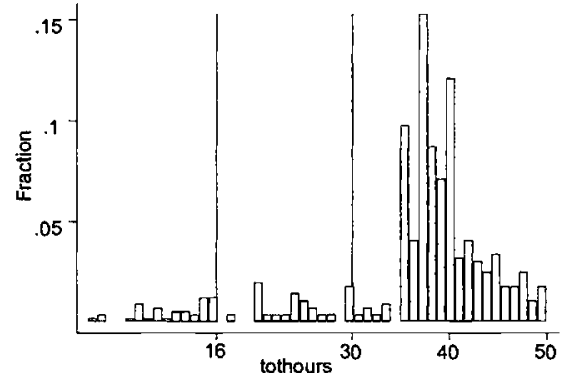

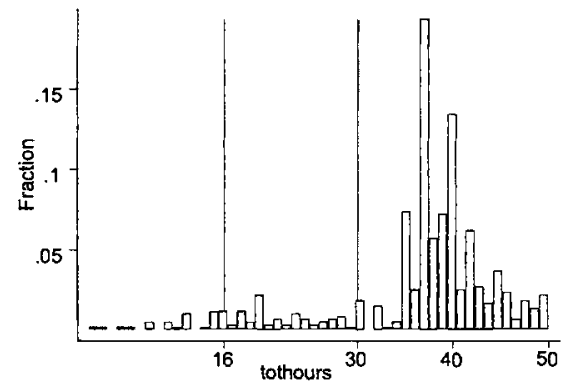

1999/00

Fig. 10.5 Weekly hours of work, single low-education women with and without children

Source: U.K. FRS data.

Note: Low education is "left school at age sixteen or before." 


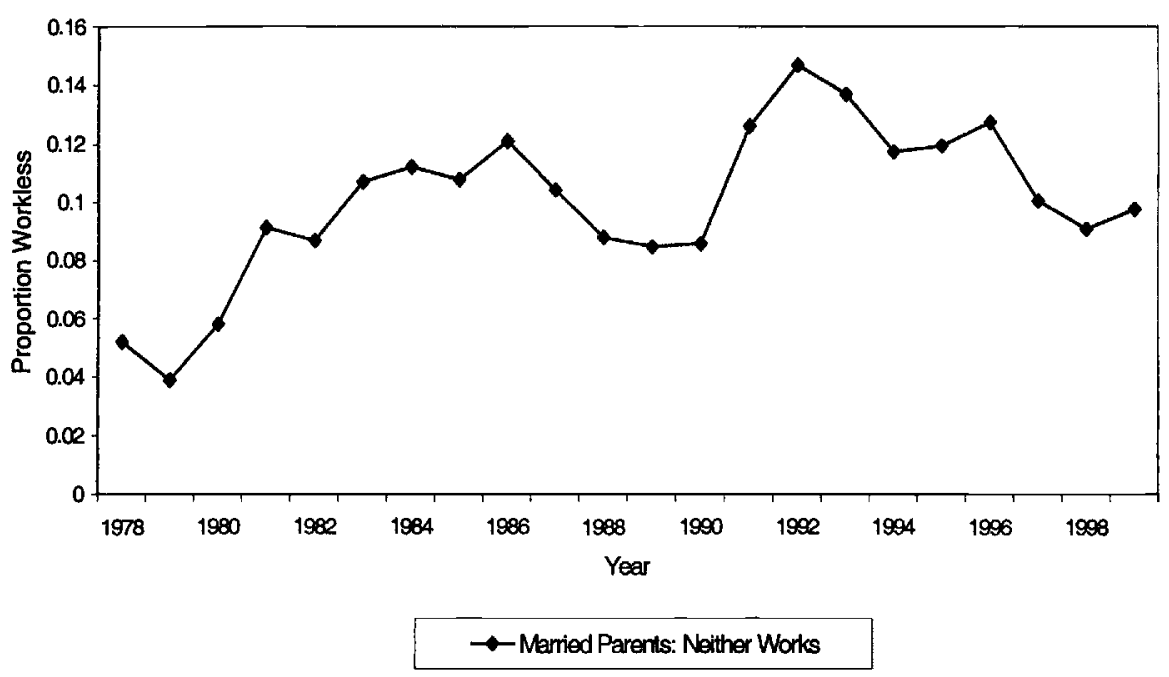

Fig. 10.6 Workless couples with children: U.K. FES low education Source: U.K. FES data.

Note: Low education is head "left school at age sixteen or before."

later period shows declines in the workless rate, down to less than 5 percent by 2000 .

\subsection{History and Reforms to In-Work Benefits}

In the United Kingdom, in-work benefit reform has been motivated as a method of poverty relief that does not create adverse work incentives. This is achieved by targeting low-income families with an income supplement that is contingent on work. Eligibility typically has been based on family income and requires the presence of children, reflecting in part the higher welfare benefits for families with children, partly a desire to help lowincome working families, and partly the costs of child care and the like. Consequently, these benefits are most heavily targeted toward single parents and low-income couples with children. Increasingly, they are also being extended to low-income workers without children. ${ }^{2}$ The family income-based eligibility rules and the interaction with other aspects of the tax and benefit system make the analysis of incentives for in-work benefits more complex than they may first appear.

Table 10.1 provides a timeline of the evolution of in-work benefits in the United Kingdom and the United States since their introduction in the 1970s. In the United Kingdom, Family Income Supplement (FIS), which 
Table 10.1

Timeline of Developments in In-Work Benefits in the United Kingdom and the United States

\begin{tabular}{ll}
\hline United States & United Kingdom \\
\hline
\end{tabular}

1971

1975 Earned Income Tax Credit (EITC)introduced with maximum credit of $\$ 400$

1987 Increase in EITC generosity and credit rate 1988

1991 Increase in EITC generosity; separate rate for two or more children; requirement for applicants to earn more than received in welfare removed; EITC no longer counted in means-tested programs' income calculations

1992

1994 Substantial increase in EITC generosity, particularly for families with 2 or more children (phased in over 1994-1996); EITC for workers without children introduced

1996

PRWORA reformed AFDC/TANF

1999

2000
Family Income Supplement (FIS) introduced as a means-tested in-work benefit

FIS replaced by Family Credit (FC) with increased generosity and lower MWRs (most instances of MWRs > 100\% were removed); 24 hours work per week needed to qualify

Qualifying conditions reduced to 16 hours per week

Extra crcdit introduced for working more than 30 hours per week

Working Families' Tax Credit replaces FC with increased generosity, longer phase-out portion, and more generous support for child care

Increase in generosity; credit paid through the wage packet

Source: Brewer (2000).

provided an earnings supplement for those families with at least one fulltime worker, was introduced in 1971. Like FIS in the United Kingdom, the EITC in the United States was also introduced in the 1970 s as a way of offsetting the payroll tax for low-income U.S. working families. The change in the composition of low-income households and the fall in labor market attachment in certain family types further refocused the policy debate in both countries and highlighted the implicit tax on income faced by such low-income families in the tax and benefit system. In the United Kingdom FIS was reformed and renamed Family Credit (FC) in 1988, which finally 
mutated into the current Working Families Tax Credit (WFTC) in 1999. Each step increased the generosity of the credit and mirrored, to some extent, the increase in generosity that occurred in the reforms to EITC in the United States.

\subsubsection{The U.K. System of In-Work Benefits and Comparison to U.S. In-Work Benefits}

The current system of in-work benefits in the United Kingdom is the WFTC. Introduced in October 1999, it increased the generosity of in-work support relative to the previous FC system through a larger adult and child credit, a less severe benefit reduction rate, and a new child care credit. The main provisions of the WFTC are outlined in Table 10.2. Eligibility for the WFTC requires having dependent children, working at least sixteen hours per week, and having income and assets below the limit. The basic weekly credit is $£ 53.15$, and it is phased out at a rate of 55 percent. Both single and married couples are eligible. A useful way of viewing the characteristics of the British system is in comparison with the U.S. EITC. Eligibility for the EITC, also outlined in table 10.2 , requires dependent children, positive earned income, and having income below the limit. The credit is phased in at a $34(40)$ percent rate and phased out at a rate of $15.98(21.06)$ percent for families with one child (two or more children).

A picture of the two systems in terms of their gross transfers is given in figure 10.7. These are evaluated for a minimum-wage single parent with one and with two eligible children in both systems, assuming that eligibility and receipt continued for a complete year. The broad similarities in the programs include larger credits for two-child families and the phasing out of the benefits. The differences are also clear from the figure. The vertical rise in eligibility in the U.K. system corresponds to the minimum hours eligibility at sixteen hours. At sixteen hours the U.K. recipient receives the maximum she is eligible for. This contrasts with the U.S. proportionate tax credit up to the maximum amount. The U.K. system also displays a much steeper withdrawal, reflecting a higher benefit reduction rate. This provides for a greater degree of targeting in the U.K. system but the potential for higher implicit tax rates. There are many additional specific idiosyncrasies to each of these systems (see Brewer [2000] for an in-depth recent comparison).

Overall, for low-earning families the U.K. system can be quite generous, significantly more so than the U.S. system. This is also clear from figure 10.8, which presents per-recipient expenditures in both countries since the 1970s. Notice also the fourfold increase in spending per recipient in the United Kingdom between 1970 and 2000. However, as figure 10.9 documents, the caseloads for these two systems are quite different. By 2000, in the United States there are nearly 20 million recipients, whereas in the United Kingdom there are approaching 1 million recipients, even though 
Working Families Tax Credit (from June 2000)

Earned Income Tax Credit (2000)
Eligibility

Must work more than 16 hours a week, have dependent children (under 16 or under 19 and in full-time education), have less than $£ 8,000$ capital. Couples need to claim jointly; need not be married. Extension to those without dependent children proposed alongside an integrated child credit.

\section{Structure}

Value of basic credit

Tapering

$$
\text { Credit is weekly. }
$$

Basic credit of $£ 53.15$ plus possible 30 hour credit of $£ 11.25$ plus credits for each child at $£ 25.60$ or $£ 26.35$ for $16-18$ s.

Child care tax credit is supplementary to this.

Beyond threshold of $£ 91.45$, tapered at $55 \%$.

\section{Interaction with Other Parts of Tax and Benefit System}

Definition of income Net income (i.e., income after income tax and national insurance).

Self-employed: same definition of income as for other tax liabilities.

Exclusions from the definition of income
Child benefit, Statutory Maternity Pay, attendance allowance, maintenance payments, Housing Benefit, and Council Tax Benefit awards
Must have positive earnings in past year and annual investment income under $\$ 2,350$.

Married couples need to file a joint tax return; unmarried couples file separately. Parents need to have a "qualifying" child (either theirs or their spouse's, or any other child that was cared for all year). "Children" are under 19, under 24 and a student, or permanently and totally dis abled.

Where a child potentially qualifies two unmarried adults for EITC, only the adult with the higher income can apply (this includes multiple tax unit-households).

Credit is annual and is a fraction of annual income up to a maximum level of $\$ 353 / \$ 2,353 / \$ 3,888$ for families with no, 1 , or more than 1 children

Phase-in threshold applies a $7.65 \% / 34 \%$ t $40 \%$ credit (for no, 1 , more than 1 children) to income until maximum credit reached.

Beyond threshold of $\$ 12,690$ ( $\$ 5,770$ for no children), tapered at $7.65 \% / 15.98 \%$ / $21.06 \%$ so that runs out at $\$ 10,380 /$ $\$ 27,413 / \$ 31,152$ (for no, 1 child, more than 1 children).

Gross earnings or "modified adjusted gross income" if modified adjusted gross income is higher and claimant is on the taper (modified adjusted gross income is income minus standard deductions for tax purposes).

Self-employed: same definition of income as for other tax liabilities.

TANF and food stamps are not taxable. 


$\begin{aligned} & \text { Programs } \\ & \text { for which } \\ & \text { awards } \\ & \text { awards }\end{aligned}$
count as
income

Programs for which count as
Federal law prohibits EITC from being treated as income for purpose of Medicaid, SSI, food stamps, and low-income housing. Since 1991, EITC did not count for AFDC assessment; states can now count EITC when determining TANF awards.

\section{Assessment and Payment Mechanism}

Assessment Assessed on average weekly income in "assessment period" prior to claim. Length of assessment period depends on frequency of claimant's earnings: 7 weeks for weekly payments, 8 weeks for fortnightly, 16 weeks for four-weekly, 4 months for monthly payments. Estimated earnings used for new workers.

Payable Weekly award fixed for 26 weeks (unless family status changes).

Paid through wage packet unless nonearner in couple elects to receive it or if self-employed.

Timing of payments aligned with timing of wages, so if worker paid monthly in arrears, credit will be paid monthly in arrears. Nonearners paid fortnightly,

To whom Couples decide who receives it. If couple paid cannot agree, then Inland Revenue will probably pay to the main carer.
Assessed at year end on past year's income.

Annual award is a refund on annual tax liability with any excess paid as a lump sum. Families have to file by April 15 each year.

Up to $\$ 1,418$ can be paid in advance through the wage packet for claimants who have federal income tax withheld from wages. Few elect for this option.

Married couples who claim the EITC have to file a joint tax return. Their EITC credit reduces the joint tax liability. They nominate who receives the payable part of the credit.

See "Eligibility" for other rules on who can claim in nonmarried couples.

Source: Brewer (2000).

the working-age population is around one-fifth of that in the United States. The rapid growth of the caseload in the United Kingdom is also significant, especially given the slower population growth in the United Kingdom: In the United States growth was from 216 million to 273 million from 1975 to 1999, representing 26.4 percent growth, in contrast to U.K. growth of 56.2 million to 59.5 million, representing just 5.3 percent growth in the United Kingdom over the same period.

So on the face of it, the U.K. system looks generous and well targeted, with a caseload that is growing rapidly. So why does it appear to have had 


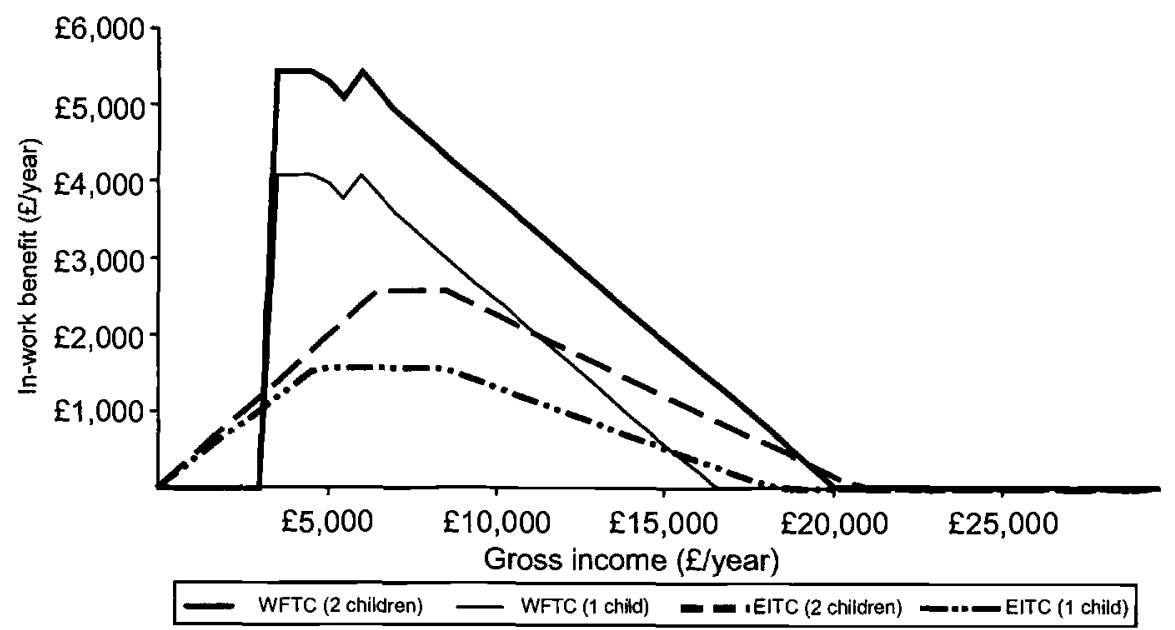

Fig. 10.7 EITC schedule and WFTC schedule, 2000 Source: Brewer (2000).

Notes: $£ 1=\$ 1.50$. Assumes 2000 tax system in United States, and 2000 tax system in United Kingdom.

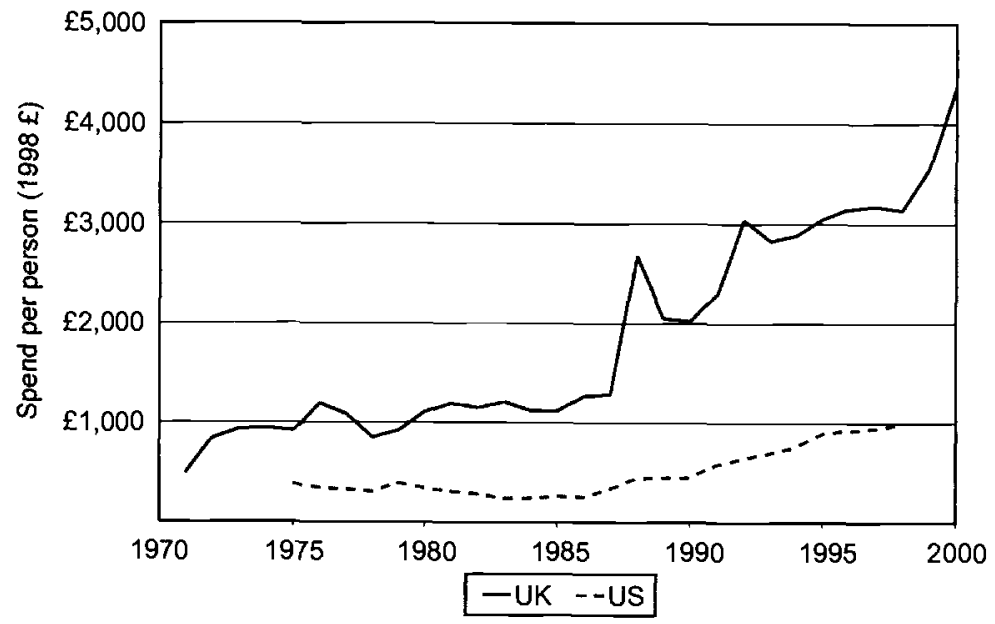

Fig. 10.8 Expenditure per claimant on in-work benefits in United Kingdom and United States

Source: Brewer (2000). 


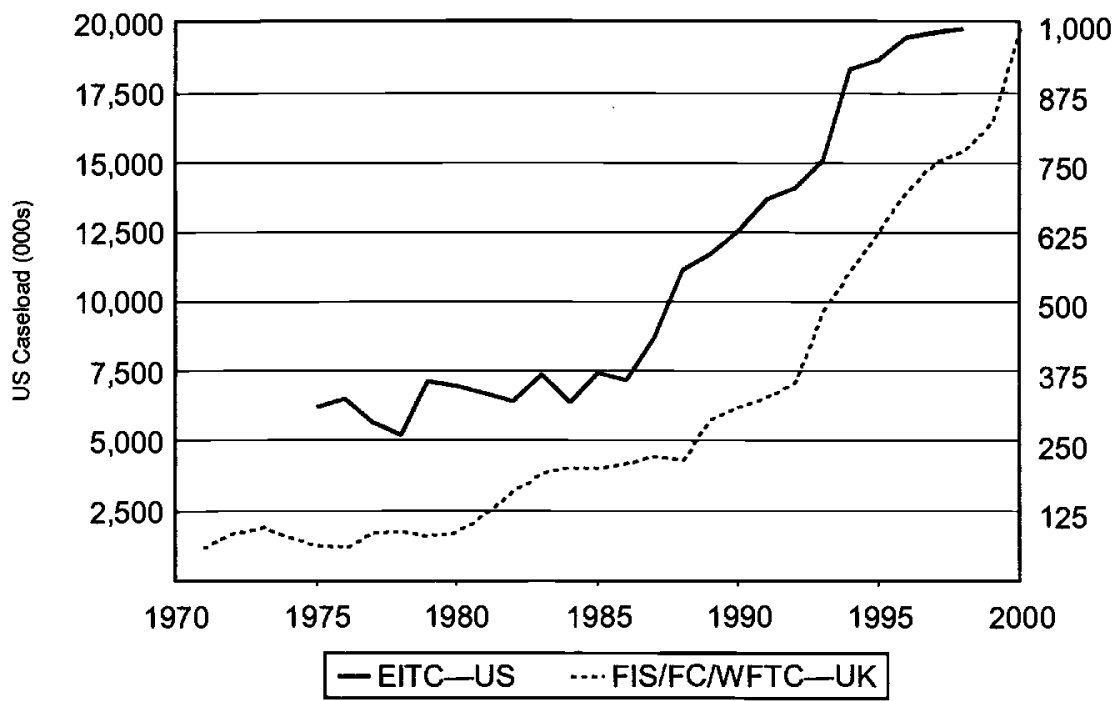

Fig. 10.9 In-work benefit caseloads

less impact on labor supply? To answer this we take a look back over the last two decades at the whole tax and benefit system in the United Kingdom as it affects work incentives.

\subsubsection{The Earlier In-Work Benefits in the United Kingdom}

In-work benefits have a long history in the United Kingdom. The first, the FIS, was introduced in 1971. This was a noncontributory benefit payable to low-income families with children, provided the head of the family was in full-time paid work (defined as thirty hours per week, or twenty-four if the individual concerned was a single parent). Entitlement depended on the family income's falling below a certain limit. The amount payable was half the difference between the family's income and the relevant limit. ${ }^{3}$ In addition to receipt of FIS, entitlement to FIS automatically conferred a number of "passport" benefits available to those on supplementary benefit - the income assistance program for those not in full-time work, including free school milk and meals, prescriptions, and dental treatment (see Dilnot, Kay, and Morris [1984] for further detail).

Although FIS clearly provided some financial incentive to work, the combined effect of the 50 percent FIS benefit reduction rate, together with the impact of housing benefit, tax, and national insurance contributions, often resulted in implicit tax rates in excess of 100 percent. For example,

3. The limits in 1983 were $£ 85.50$ per week for a one-child family, with $£ 9.50$ for each subsequent child, with a maximum payment of $£ 22$ per week. 
under the FIS system an eligible worker with housing costs would pay a 25 percent basic tax rate, a national insurance contribution of 7 percent, a 50 percent benefit reduction rate on FIS, and an effective Housing Benefit reduction rate of 23 percent, resulting in an implicit tax rate of 105 percent. After the FC reform this would reduce to 97 percent-still high, but below 100 percent (see Dilnot and Walker 1992).

\section{Family Credit ( FC)}

Introduced in 1988, FC was an extension of FIS and was designed to increase generosity and remove tax rates in excess of 100 percent. It achieved the later objective by fully integrating the in-work credit with the rest of the tax and benefit system. An unusual feature of the FC system, retained from the FIS, was the minimum weekly hours eligibility criterion. At its introduction this was set at twenty-four hours but then reduced to sixteen hours in April 1992 to encourage part-time work by lone parents with young children. The FIS had a minimum hours criteria set at thirty hours for workers in couples and twenty-four hours for single parents. To partially offset any adverse incentive effects for full-time work from the later lower hours eligibility level, a further supplementary credit at thirty hours per week was introduced in April 1995.

In the FC system each eligible family was paid a credit up to a maximum amount that depended on the number of children. Eligibility depended on family net income's being lower than some threshold ( $£ 79.00$ per week in 1998-1999). As incomes rose, the credit was withdrawn at a rate of 70 percent. In 1996 average payments were around $£ 57$ a week, and take-up rates stood at 69 percent of eligible individuals and 82 percent of the potential expenditure.

The sixteen-hour reform, proposed in the 1988 review of the U.K. benefit system, only became effective in April 1992 and moved the hours eligibility rule from twenty-four hours per week to sixteen hours per week (see Blundell and Meghir [2002] for a detailed description of this reform). Figure 10.10 shows the impact on the budget constraint of a typical single parent. ${ }^{4}$

Family Credit is treated as income in calculating other benefits incomes-this is not the case for the U.S. system. In the United Kingdom, this has the effect of dampening down the incentives in the underlying inwork benefit system. The impact of Housing Benefit (rent rebate), which is withdrawn at 65 percent, is particularly notable. In the United Kingdom once family income falls below a specific level all rental payments are covered through the benefit system. For example, in panel B of figure 10.10,

4. These are constructed using the IFS tax and benefit simulation model TAXBEN (see www.ifs.org.uk) designed to utilize the Family Expenditure Survey (FES) and the FRS used in this paper (see the data appendix). 
A

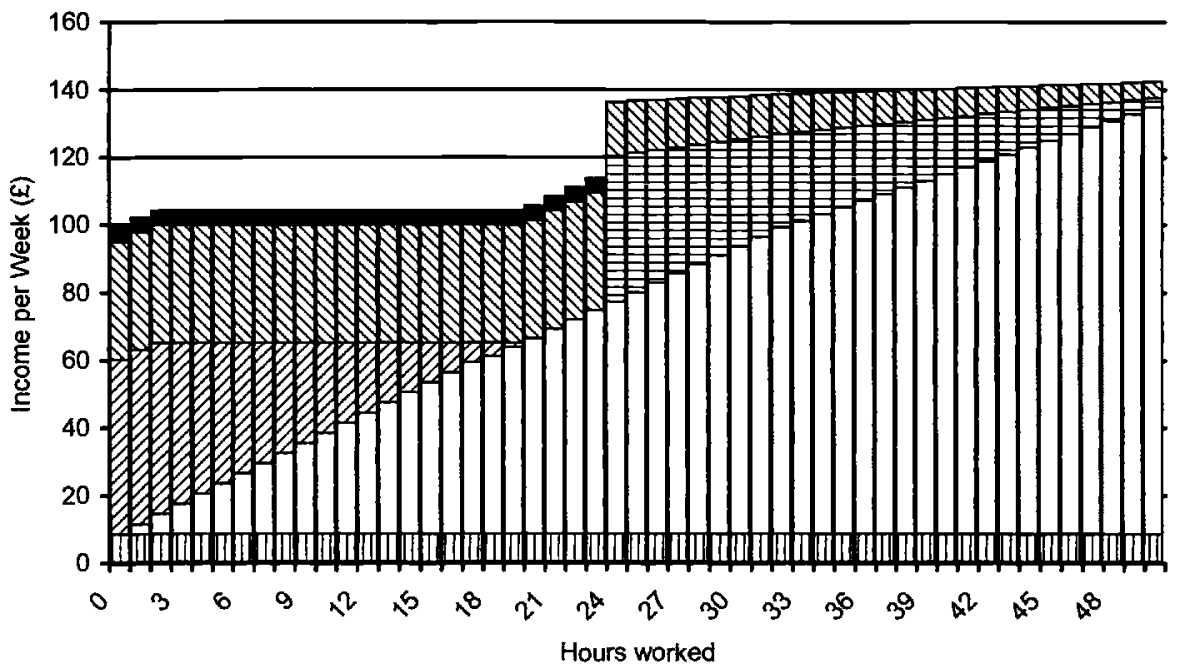

\begin{tabular}{|l|}
\hline$\square$ Child Benefit \\
$\square$ Net Earnings \\
$\square$ Income Support \\
$\mathrm{Q}$ Family Credit \\
$\square$ Rent Rebate \\
Local Tax Rebate
\end{tabular}

Fig. 10.10 The 1992 hours reform to $\mathrm{FC}$ and other taxes and benefits: $A$, single parent in 1991; $B$, single parent in 1992

Notes: A, Single parent, April 1991, earning $£ 3.00$ per hour; $B$, single parent, April 1992, earning $£ 3.00$ per hour.

when the FC becomes available at sixteen hours, the housing benefit decreases substantially, leading to a minimal increase in income.

Similar budget constraints with very similar effects can be drawn for a low-wage couple with children (see Blundell 2001). These figures show our first central point - the importance of allowing for the interaction with other benefits and taxes, especially where means-tested programs, such as Housing Benefit in the United Kingdom, extend up the income distribution to such an extent that they overlap extensively with in-work benefits.

Although these budget constraint pictures show a high replacement rate, they do nevertheless suggest some financial incentive to take a sixteenhour job after the 1992 reform. Do the data confirm this? Recall the picture of hours of work for low-education single parents in the United Kingdom in section 10.2. This showed a strong peak at the sixteen-hour point. Blundell (2000) presents a picture of the hours changes before and after the 1992 reform. It is notable that for single mothers a spike at twenty-four hours 
B

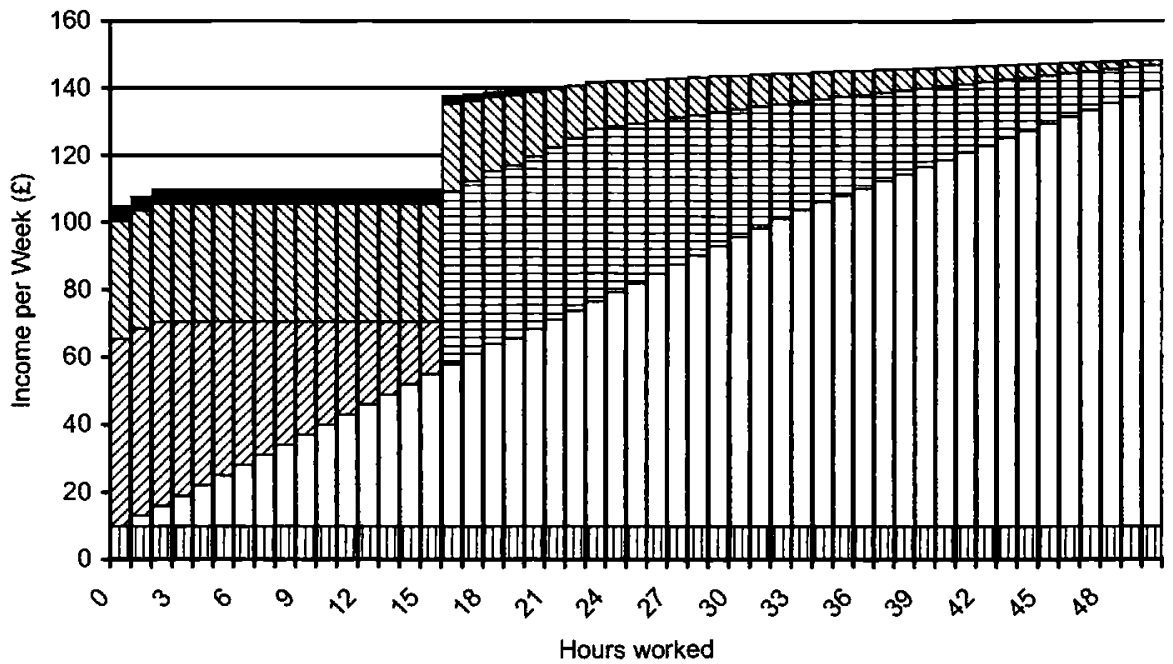

\begin{tabular}{|l|}
\hline$\square$ Child Benefit \\
$\square$ Net Earnings \\
$\square$ Income Support \\
$\Xi$ Family Credit \\
$\square$ Rent Rebate \\
Local Tax Rebate
\end{tabular}

Fig. 10.10 (cont.) The 1992 hours reform to $F C$ and other taxes and benefits: $A$, single parent in $1991 ; B$, single parent in 1992

Notes: $A$, Single parent, April 1991, earning $£ 3.00$ per hour; $B$, single parent, April 1992, earning $£ 3.00$ per hour.

tends to disappear in 1992 as a spike at sixteen hours becomes more pronounced. This 16-hour eligibility rule has been maintained throughout all the subsequent changes to in-work benefits in the United Kingdom. Interestingly, as we saw in figure 10.5 , the spike at this point in the hours distribution has also remained a predominant feature of the data for those most likely to be eligible for in-work benefits in the United Kingdom. ${ }^{5}$

Figure 10.10 also highlights our second central point - the out-of-work benefit system over this period was relatively generous and implied a fairly high replacement rate for a low-wage working parent. For example, income support and housing benefits amount to about $£ 100$ per week, compared to a minimum wage in 1999 of $£ 3.60$ per hour.

In the following discussion we will show that increases in the value of in-

5. As mentioned previously, a further thirty-hour supplement to FC in the United Kingdom was introduced in 1995 (see Duncan and Giles [1996] for a detailed description). This has also been maintained throughout all subsequent reforms and is what gives rise to the second peak in the in-work benefit payments in figure 10.7. 
work benefits in the United Kingdom typically have been matched by similar increases in the value of out-of-work benefits. Consequently, replacement rates have remained quite high, contrasting quite dramatically with the recent experience in the United States. We return to this theme in the following discussion but first complete our brief discussion of the history of U.K. in-work benefit reforms.

\section{The Working Families Tax Credit (WFTC)}

The replacement of FC - the WFTC - was substantially more generous and was fully phased in from April 2000. It increased the level of in-work support relative to the FC system in four ways: (1) by enhancing the credit for families with younger children; (2) by increasing the threshold; (3) by reducing the benefit reduction rate from 70 percent to 55 percent; and (4) by incorporating a new childcare credit of 70 percent of actual child care costs up to a quite generous limit. The effects of these changes relative to FC are shown in figure 10.11.

The largest cash gains go to those people who are just at the end of the FC benefit reduction taper. The impact on the budget constraint of a single parent is presented in figure 10.12. Again, a similar constraint can be calculated for couples with children (see Blundell 2001). Indeed, because couples typically have higher housing costs and are eligible for higher levels of in-work credit, the replacement rate for lower hours is even higher. If anything, this reform increases the incentives for full-time jobs. As we find in section 10.5 , this is borne out in the simulation model.

This discussion once again highlights the importance of interactions between benefits. The WFTC payments are counted as income in computing the entitlement to other benefits, such as Housing Benefit (Rent Rebate). The budget constraints show the importance of these interactions in reducing the impact of the increased generosity in the WFTC.

Child care credit increases the maximum amount of WFTC by 70 per-

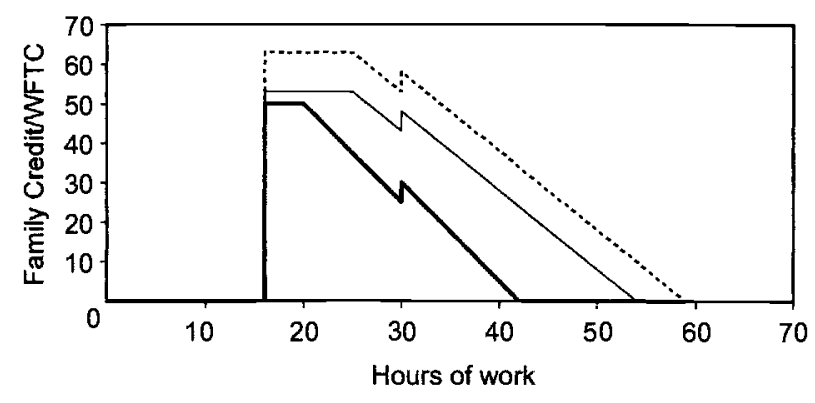

..... WFTC with childcare - WFTC - Family Credit

Fig. 10.11 WFTC and FC 
A

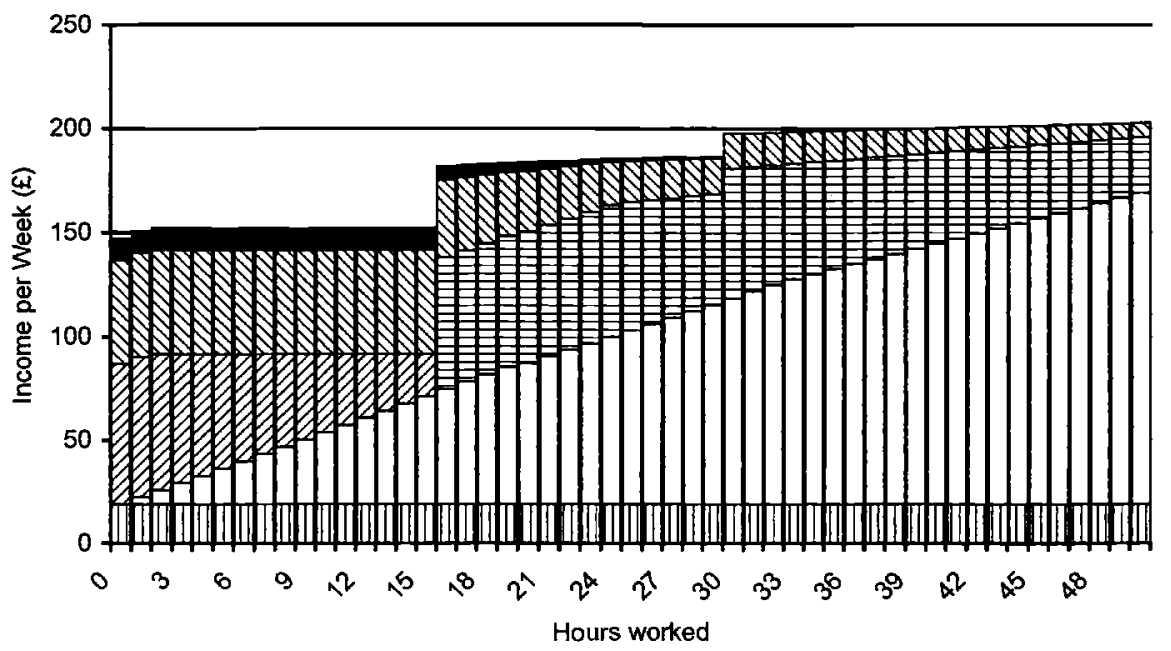

\begin{tabular}{|l|}
\hline Child Benefit \\
$\square$ Net Earnings \\
$\square$ Income Support \\
$\square$ Family Credit \\
$\square$ Rent Rebate \\
Local Tax Rebate
\end{tabular}

Fig. 10.12 $A$, Single mother before WFTC; $B$, single mother after WFTC

Notes: $A$, Single parent, April 1997, earning $\mathfrak{£} 3.50$ per hour (2000 prices); $B$, single parent, April 2000 , earning $£ 3.50$ per hour (2000 prices).

cent of child care costs up to a maximum of $£ 100$ per week for those with one child or $£ 150$ per week for those with two or more children. The child care credit component is available to all working lone parents and to couples in which both partners work more than sixteen hours per week. ${ }^{6}$ The requirement that both parents work helps to offset the negative incentive to work on the second worker in a couple implicit in the family-based calculation of the level of the credit in both the WFTC. We return to the importance of this adverse effect on couples in our detailed discussion of the WFTC reform in section 10.5. It is also important for the EITC and reoccurs in our discussion of the EITC reforms in section 10.4.

\subsubsection{The Impact on Work Incentives}

In the previous discussion the importance of interactions of in-work be-

6. This is not included in the calculation of the budget constraint figures because the takeup of child care credits has been rather low. As we point out in section 10.5, recent figures of take-up under WFTC show it to have remained low but increasing quite rapidly. 


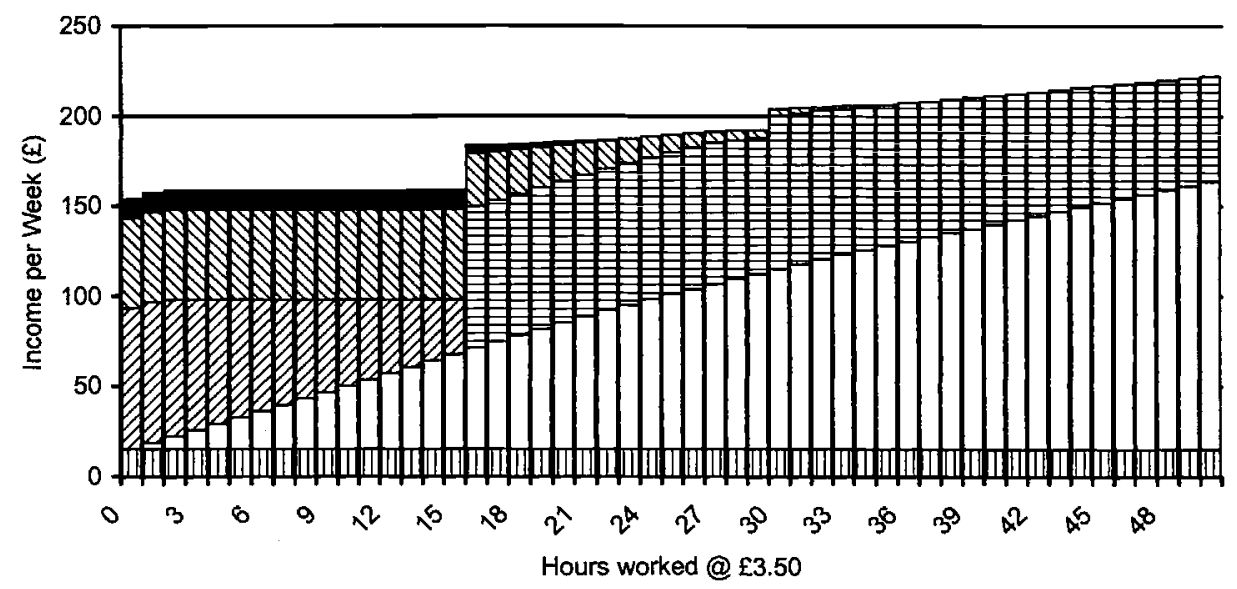

\begin{tabular}{|l}
\hline Child Benefit \\
$\square$ Net Earnings \\
$\square$ Income Support \\
星 Family Credit \\
$\square$ Rent Rebate \\
Local Tax Rebate
\end{tabular}

Fig. 10.12 (cont.)

nefits with other benefits in the United Kingdom and the level of those other benefits has been highlighted. It is central to our understanding of the financial incentives to work for low-wage parents in the United Kingdom. We have seen that the impact of these interactions is to dampen, often quite dramatically, the financial incentives to work. To evaluate the likely effect of these reforms to the financial incentives to work facing the target groups in the U.K. population over the 1980s and 1990s, we consider an overall view of changes to the U.K. income support and benefit system.

We first consider the impact of all reforms on the maximum amount of out-of-work income support and the maximum amount of in-work benefit over this period since the late 1970 s. These figures are presented in figure 10.13 for a single mother in the United Kingdom. These maximum amounts simply depend on the hours worked and the number of children. They underscore the second important feature of the U.K. system that is in direct contrast to the U.S. experience. The real value of the maximum amount of income support in and out of work has remained almost constant over these two decades. Where in-work credits have increased, especially with regard to the recent very large increases in the real value of child 
A

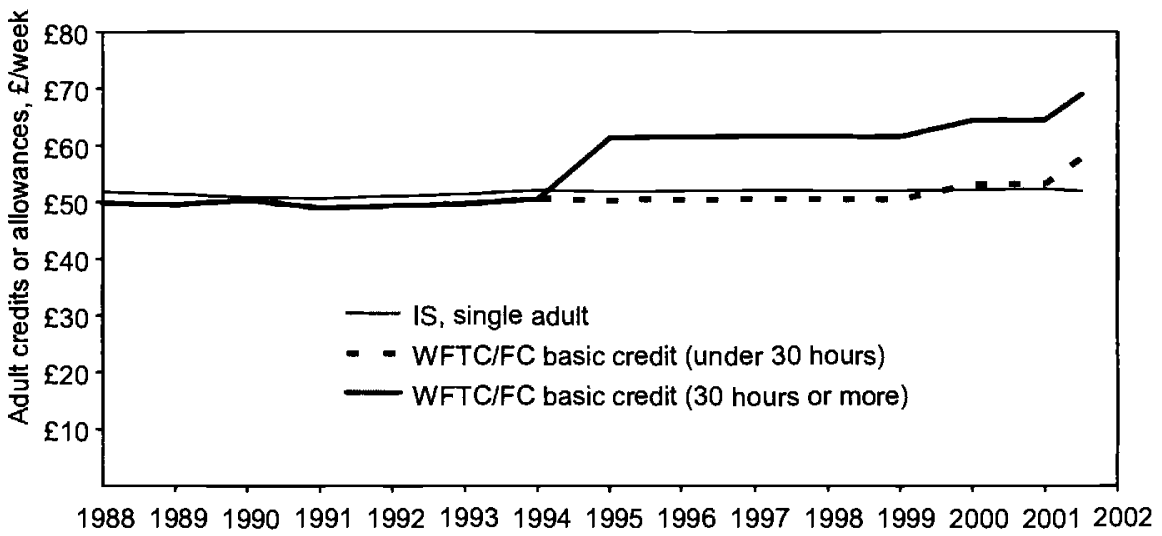

B

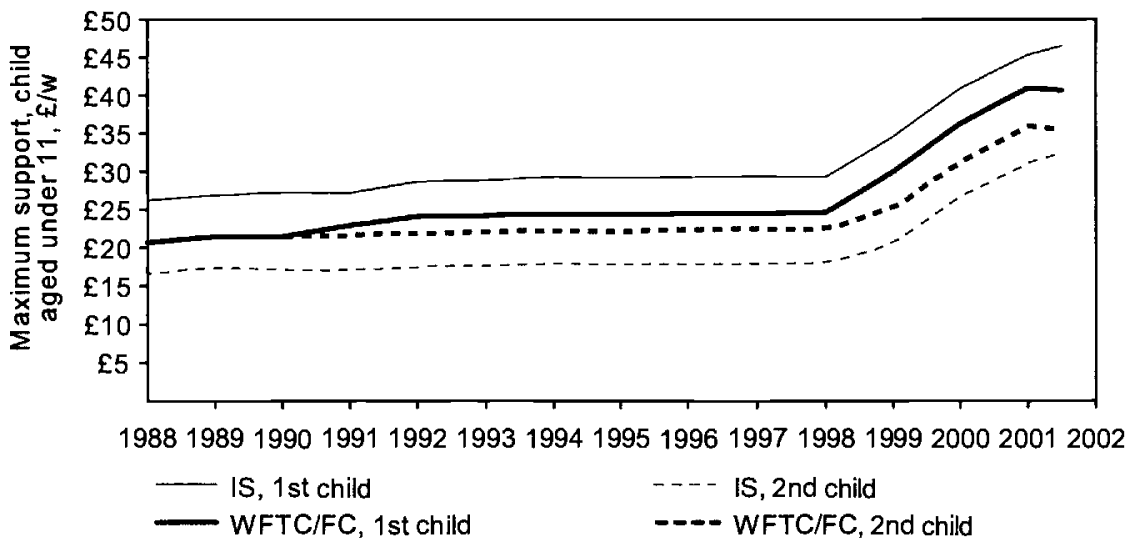

Fig. 10.13 $A$, Adult credit and Income Support: single mother in United Kingdom; $B$, child credit and Income Support: single mother in United Kingdom Source: A, Brewer, Myck, and Reed (2001).

credits (see panel B of figure 10.13), they have been matched by very similar rises in the child component of out-of-work income support for lowincome families. The only slight divergence from this rule came in the 1995 introduction of a supplementary adult credit at thirty hours of work.

Interesting as these figures are, they clearly miss the differences that have occurred due to changes in the minimum hours requirement and to interactions with taxes and other benefits in calculating actual receipts rather than maximum eligible amounts. Figure 10.14 at tempts to capture this. We first ignore Housing Benefit and consider the financial incentives for a single parent with two children (one aged less than five and one aged between five and ten). They assume that if she works she is paid at the real value of the minimum wage in 1999 ( $£ 3.60$ per hour). Three possible weekly 

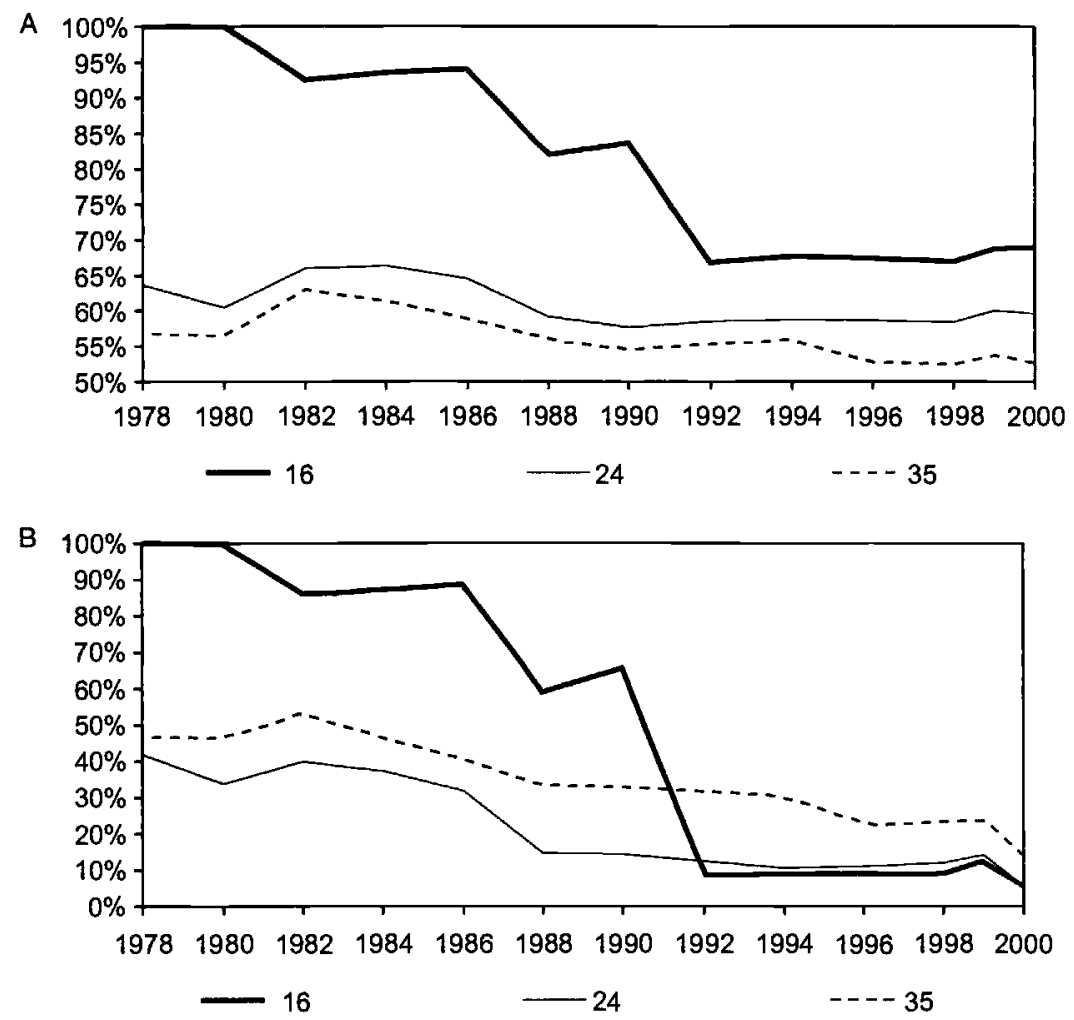

Fig. 10.14 $A$, Replacement rate by hours of work for single mother in United Kingdom: without housing costs; $B$, average tax rate for single mother in United Kingdom: without housing costs

hours of work are considered: sixteen, twenty-four, and thirty-five. Panel A of figure 10.14 presents the replacement rate computed as the ratio of total benefit income if out of work and total disposable income if in work. Panel B of figure 10.14 shows the corresponding average tax rate calculated as the proportionate loss in earnings in taking a minimum-wage job at these hours of work.

At the beginning of the period the replacement rates for twenty-fourand thirty-five-hour jobs were around 60 percent and relatively stable over the early and mid-1980s, falling with the introduction of FIS in 1988, especially for twenty-four-hour jobs. The replacement rate fell back a little in 1995 for higher-hour workers after the thirty-hour supplement in $1995 .^{7}$ For sixteen-hour jobs the replacement rate is very high indeed. The biggest

7. The rise in the replacement rate in 1999 reflects the removal of one parent benefit. This is reversed by the introduction of WTFC in the final year of figure 10.14 . 
changes in these figures come from the reform in the late 1980 s that reduced eligibility for in-work benefits to sixteen hours from twenty-four hours.

Figure 10.15 presents the replacement rate and the average tax rates, including Housing Benefit. The overall pattern is very similar, but the dampening effect of Housing Benefit is clearly visible. For example, the replacement rates are, in general, higher for the twenty-four- and thirty-five-hour jobs than in panel A of figure 10.14. The drop in the rates for sixteen-hour jobs with the 1992 reform is still important but less dramatic.

These figures serve to underscore our two key points with regard to the benefit and tax credit system in the United Kingdom. First, the interaction of work-based credits with the tax and benefit system has the effect of dampening the financial incentives. This is not a feature of the U.S. EITC. Second, where generosity in the work-based credits has increased, it has

A

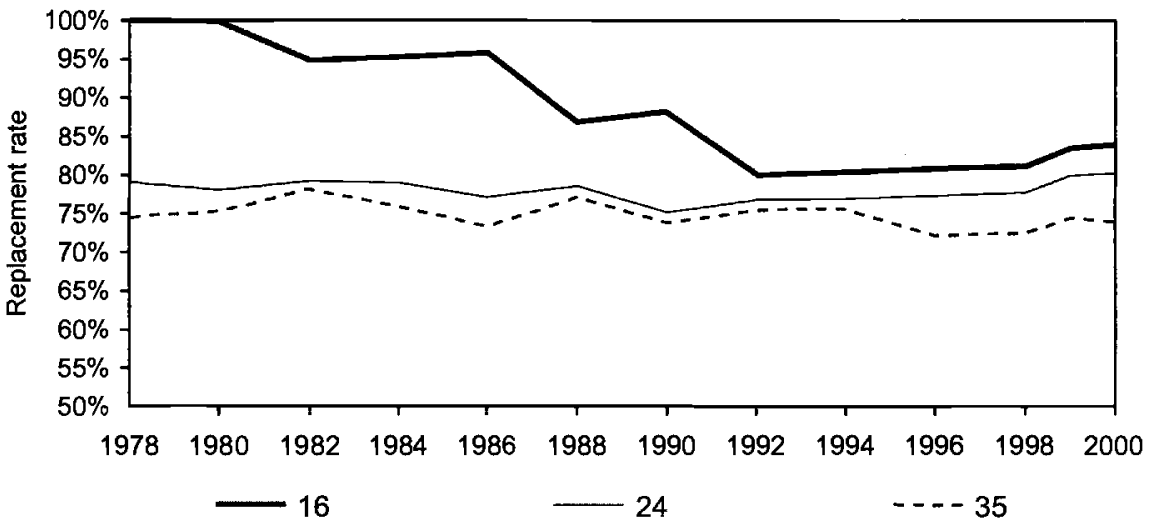

B

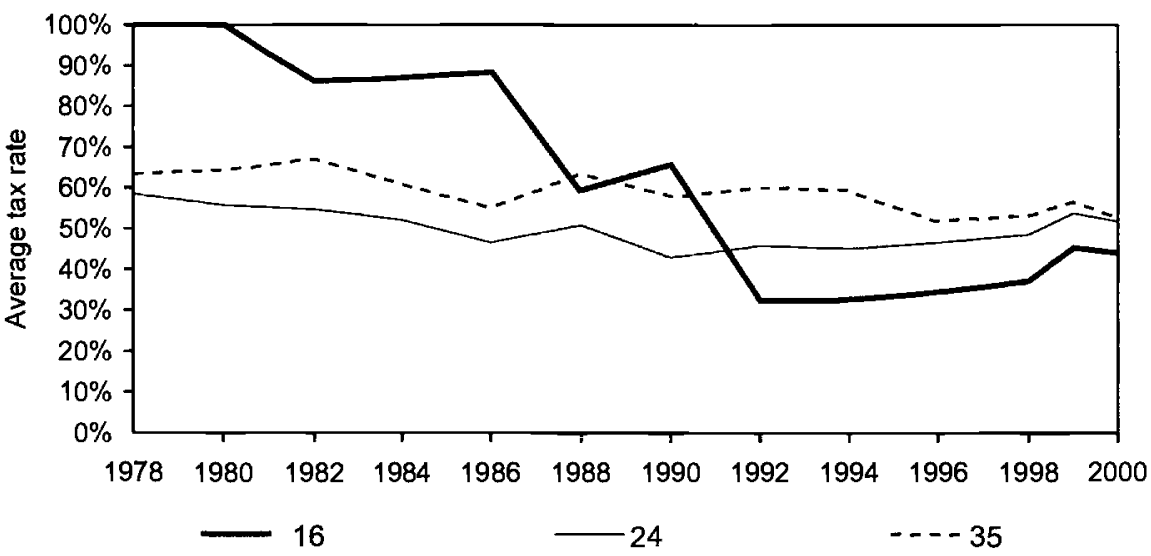

Fig. 10.15 $A$, Replacement rate by hours of work for single mother in United Kingdom: with housing costs and housing benefit; $B$, average tax rate for single mother in United Kingdom: with housing costs 
been typically matched by increases in out-of-work income support for families with children. This has left the replacement rate and effect tax rates rather stable over time. Again, this contrasts importantly with the U.S. system, where there has been a relative decline in the value of out-of-work income support. The generosity of Housing Benefit and child additions to income support in the United Kingdom has left the level of out-of-work income for families with children at an increasingly higher rate than that in the United States. Four-fifths of all single parents on Income Support in 1999 were also in receipt of Housing Benefit.

Two other features of the U.K. experience are probably worth highlighting at this juncture. First, the U.K. welfare system provides benefits not only to lone parents but also to couples with children. This is in contrast to the United States, where couples with children are provided substantially more limited benefits. In fact, in the United Kingdom, Housing Benefit and Income Support are generally higher for couples due to higher housing costs and larger families. The upshot of this is that the budget constraint and replacement rate figures for couples on low incomes look very similar to those for single parents; indeed, the replacement rates can be quite a bit higher. This certainly has some bearing on the much larger incidence of workless couples with children in the United Kingdom.

The second factor, which adds to the findings so far, is the growing importance of housing costs for low-income families over the last two decades. This reflected a strong increase in the real level of rents paid in both private and public housing over the 1980s. Even though the rules of the housing benefit system were left relatively unchanged, the eligible amounts and receipts increased dramatically over this period. This was one of the main factors behind the rise in out-of-work incomes received by low-income families in rented accommodation over the 1980s (see Giles, Johnson, and McCrae [1997] and Dickens and Ellwood [chap. 8 in this volume], for example). In figure 10.15 the housing benefit is kept at the same 2000 real value throughout so that the true picture for someone in the rented sector would have an increasing financial disincentive to work, counteracting increases in in-work benefits.

\subsection{Evidence from the U.S. Reforms}

\subsubsection{Programs for the Low-Income Population in the United States}

Out-of-work benefit programs through the welfare system have been the backbone of assistance to low-income persons in the United States. Since 1935, the Aid to Families with Dependent Children (AFDC) has provided cash transfers to needy single parents with children. Since the 1960s and 1970s, the social safety net expanded to provide in-kind benefits to needy individuals. The primary in-kind benefit programs include Food Stamps, 
Medicaid (health insurance), and housing subsidies. Eligibility for these welfare programs requires satisfying resource restrictions in the form of limits on current income and assets. In general, these welfare programs have primarily been limited to single parents with children, largely excluding married couples and nonelderly persons without children. Although some working families receive welfare benefits, they are not in-work programs. As with most welfare programs, families receive the maximum benefit if they are not working and face high benefit reduction rates with increases in family earnings. As is well recognized, the programs provide adverse work incentives.

The Earned Income Tax Credit began in 1975 as a modest program aimed at offsetting the Social Security payroll tax for low-income families with children. As we will discuss more, the generosity of the EITC increased in the tax acts of 1986, 1990, and 1993. The contrasts between the EITC and traditional welfare benefits are many. First, the EITC is provided through the tax system rather than the welfare system. Second, eligibility for the EITC is available to all low-income families with children, independent of marital status. Third, receipt of the credit requires positive family earnings. Consequently, the EITC creates positive incentives to work for single parent families. Because the credit is based on family earnings, however, the credit can create adverse incentives to work among married couples (Eissa and Hoynes 2004).

\section{Reforms to the Earned Income Tax Credit (EITC)}

The basic structure of the EITC has not changed substantially in the twenty-five years since its introduction. Eligibility for the EITC depends on the taxpayer's earned income (or in some cases adjusted gross income) and the number of qualifying children who meet certain age, relationship, and residency tests. Several features of the credit are different from the U.K. in-work programs. First, the credit is within the tax system and is a refundable credit, so a taxpayer with no federal tax liability, for example, would receive a tax refund from the government for the full amount of the credit. Second, the credit amount depends on annual income and earnings, and virtually all recipients receive the credit in one lump sum at the end of the year. Last, the EITC does not count as income in welfare benefit formulas. As we will see, this difference turns out to be very important.

The amount of the credit to which a taxpayer is entitled depends on the taxpayer's earned income, adjusted gross income, and, since 1991, the number of EITC-eligible children in the household. There are three regions in the credit schedule. The initial phase-in region transfers an amount equal to the subsidy rate times their earnings. In the flat region, the family receives the maximum credit. In the phase-out region, the credit is phased out at some phase-out rate.

Table 10.3 summarizes the parameters of the EITC over the history of the program. The real value of the credit increased only modestly in the 
U.S. Earned Income Tax Credit Parameters

\begin{tabular}{|c|c|c|c|c|c|c|}
\hline Year & Group & $\begin{array}{l}\text { Phase-In } \\
\text { Rate }(\%)\end{array}$ & $\begin{array}{c}\text { Phase-In } \\
\text { Range }\end{array}$ & $\underset{\text { Credit }}{\text { Maximum }}$ & $\begin{array}{c}\text { Phase-Out } \\
\text { Rate }(\%)\end{array}$ & $\begin{array}{c}\text { Phase-Out } \\
\text { Range }\end{array}$ \\
\hline $1975-1978$ & $1+$ children & 10.0 & $\$ 0-4,000$ & $\$ 400$ & 10.0 & $\$ 4,000-8,000$ \\
\hline $1979-1984$ & $1+$ children & 10.0 & $\$ 0-5,000$ & $\$ 500$ & 12.5 & $\$ 6,000-10,000$ \\
\hline $1985-1986$ & $1+$ children & 11.0 & $\$ 0-5,000$ & $\$ 550$ & 12.22 & $\$ 6,500-11,000$ \\
\hline \multicolumn{7}{|l|}{ TRA 86} \\
\hline 1987 & $1+$ children & 14.0 & $\$ 0-6,080$ & $\$ 851$ & 10.0 & $\$ 6,920-15,432$ \\
\hline 1988 & $1+$ children & 14.0 & $\$ 0-6,240$ & $\$ 874$ & 10.0 & $\$ 9,840-18,576$ \\
\hline 1989 & $1+$ children & 14.0 & $\$ 0-6,500$ & $\$ 910$ & 10.0 & $\$ 10,240-19,340$ \\
\hline 1990 & $1+$ children & 14.0 & $\$ 0-6,810$ & $\$ 953$ & 10.0 & $\$ 10,730-20,264$ \\
\hline \multicolumn{7}{|l|}{ OBRA90 } \\
\hline \multirow[t]{2}{*}{1991} & 1 child & 16.7 & $\$ 0-7,140$ & $\$ 1,192$ & 11.93 & $\$ 11,250-21,250$ \\
\hline & $2+$ children & 17.3 & & $\$ 1,235$ & 12.36 & \\
\hline \multirow[t]{2}{*}{1992} & 1 child & 17.6 & $\$ 0-7,520$ & $\$ 1,324$ & 12.57 & $\$ 11,840-22,370$ \\
\hline & $2+$ children & 18.4 & & $\$ 1,384$ & 13.14 & \\
\hline \multirow[t]{2}{*}{1993} & 1 child & 18.5 & $\$ 0-7,750$ & $\$ 1,434$ & 13.21 & $\$ 12,200-23,050$ \\
\hline & $2+$ children & 19.5 & & $\$ 1,511$ & 13.93 & \\
\hline \multicolumn{7}{|l|}{ OBRA93 } \\
\hline \multirow[t]{3}{*}{1994} & 1 child & 26.3 & $\$ 0-7,750$ & $\$ 2,038$ & 15.98 & $\$ 11,000-23,755$ \\
\hline & $2+$ children & 30.0 & $\$ 0-8,425$ & $\$ 2,528$ & 17.68 & $\$ 11,000-25,296$ \\
\hline & No children & 7.65 & $\$ 0-4,000$ & $\$ 306$ & 7.65 & $\$ 5,000-9,000$ \\
\hline \multirow[t]{3}{*}{1995} & 1 child & 34.0 & $\$ 0-6,160$ & $\$ 2,094$ & 15.98 & $\$ 11,290-24,396$ \\
\hline & $2+$ children & 36.0 & $\$ 0-8,640$ & $\$ 3,110$ & 20.22 & $\$ 11,290-26,673$ \\
\hline & No children & 7.65 & $\$ 0-4,100$ & $\$ 314$ & 7.65 & $\$ 5,130-9,230$ \\
\hline \multirow[t]{3}{*}{1996} & 1 child & 34.0 & $\$ 0-6,330$ & $\$ 2,152$ & 15.98 & $\$ 11,650-25,078$ \\
\hline & $2+$ children & 40.0 & $\$ 0-8,890$ & $\$ 3,556$ & 21.06 & $\$ 11,650-28,495$ \\
\hline & No children & 7.65 & $\$ 0-4,220$ & $\$ 323$ & 7.65 & $\$ 5,280-9,500$ \\
\hline \multirow[t]{3}{*}{2000} & 1 child & 34.0 & $\$ 0-6,900$ & $\$ 2,353$ & 15.98 & $\$ 12,700-27,413$ \\
\hline & $2+$ children & 40.0 & $\$ 0-9,700$ & $\$ 3,888$ & 21.06 & $\$ 12,700-31,152$ \\
\hline & No children & 7.65 & $\$ 0-4,600$ & $\$ 353$ & 7.65 & $\$ 5,800-10,380$ \\
\hline
\end{tabular}

Sources: U.S. House of Representatives (2000) and authors' calculations from OBRA93.

early years and was due mostly to inflation. ${ }^{8}$ The 1987 expansion of the EITC, passed as part of the Tax Reform Act of 1986 (TRA86), represents the first major expansion of the EITC. The TRA86 increased the subsidy rate for the phase-in of the credit from 11 percent to 14 percent and increased the maximum credit from $\$ 550$ to $\$ 851$ ( $\$ 788$ in 1986 dollars). The phase-out rate was reduced from 12.22 percent to 10 percent.

The 1991 expansion, contained in the Omnibus Reconciliation Act of 1990 (OBRA90), increased the maximum credit and introduced separate credit rates for families with two or more children. By 1993, a family with two or more children could receive a maximum credit of $\$ 1,511, \$ 77$ more than a family with one child.

The largest single expansion over this period was contained in the Om-

8. The EITC was first indexed to inflation in 1987. 
nibus Reconciliation Act of 1993 (OBRA93) legislation. The 1993 expansion of the EITC, phased in between 1994 and 1996, led to an increase in the subsidy rate from 19.5 percent to 40 percent ( 18.5 to 34 percent) and an increase in the maximum credit from $\$ 1,511$ to $\$ 3,556$ ( $\$ 1,434$ to $\$ 2,152)$ for taxpayers with two or more children (taxpayers with one child). This expansion was substantially larger for those with two or more children. The phase-out rate was also raised, from 14 percent to 21 percent ( 13 to 16 percent) for taxpayers with two or more children (taxpayers with one child). Overall, the range of the phase-out was expanded dramatically, such that by 1996 a couple with two children would still be eligible with income levels of almost $\$ 30,000$.

To summarize the changes in the EITC, figure 10.16 presents the credit schedule in 1984, 1990, 1993, and 1996. This shows that 1986 and 1993 expansions were the most substantial.

\section{Reforms to the AFDC Program}

This period saw not only expansions in the EITC but also important changes in AFDC, changes that are important for analyzing the financial incentives to work. These changes generally take the form of making the out-of-work benefits less generous and creating greater work incentives. This is the opposite of the trend in the United Kingdom. This difference is critical to understanding the "puzzle" here. From the late 1970s to the early 1990 s the only substantial change in the AFDC program was a gradual erosion in the real value of benefits. For example, between 1979 and 1993 real benefits for welfare recipients fell by over 30 percent. Even taking into account falling real wages for the low-skilled population in this period, benefits relative to wages still fell by over 15 percent (Hoynes and MaCurdy 1994). Beginning in the early to mid-1990s, some states made significant changes to their AFDC programs through the provision of federal waivers. These waivers, as discussed recently by Meyer and Rosenbaum (2001) and Schoeni and Blank (2000), increased work incentives by reducing the implicit tax rate on earned income and expanding work requirements. This led up to major federal welfare reform legislation passed in 1996 (the Personal Responsibility and Work Opportunity Reconciliation Act or PRWORA) that ended the entitlement nature of the AFDC program. The AFDC program was abolished and replaced by Temporary Assistance for Needy Families (TANF).

The major provision of this act is the addition of lifetime time limits on welfare receipt, typically five years in length. In addition, states are required to increase the work effort of welfare recipients and have been given much more flexibility to redesign programs to achieve this goal. Overall, these changes have unambiguously led to an increase in the financial incentive to work.

As we discussed previously, it is important whether the income from in- 


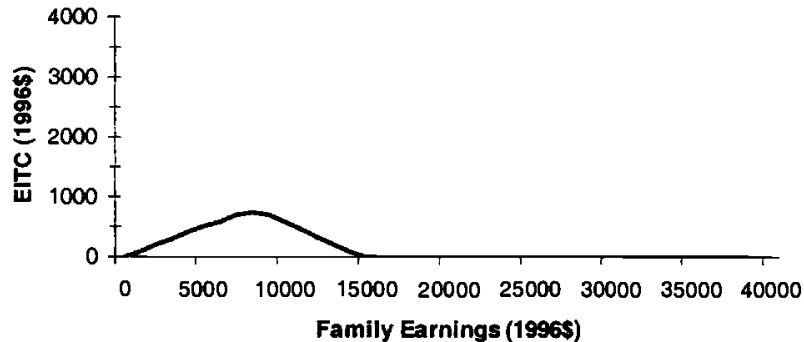

All Families

Taxyear $=1993$

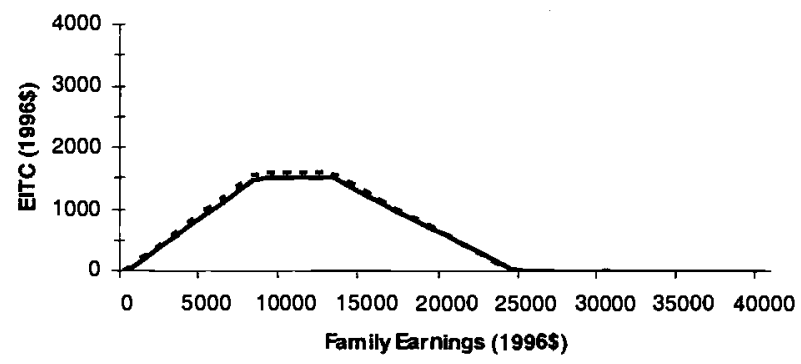

-1 Child $-\cdots-2+$ children

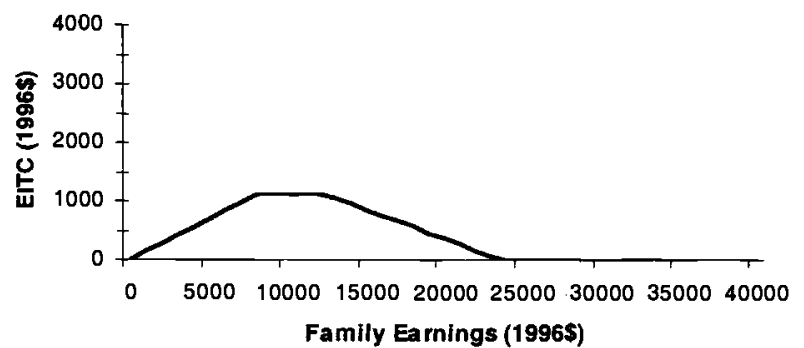

All Families

Taxyear $=1996$

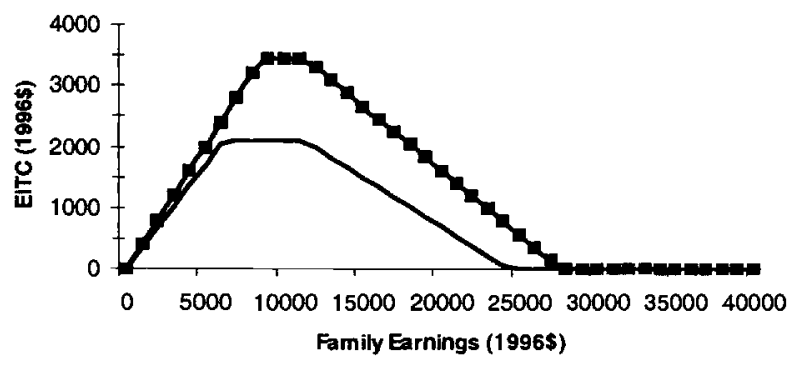

Fig. 10.16 The EITC reforms (1996 dollars) 
work programs is taken into account in the calculation of welfare benefits. Over time, the rules surrounding the treatment of income from the EITC have changed (U.S. House of Representatives 2000). Between 1975 and 1978 , the EITC did not count as income for the calculation of welfare benefits. ${ }^{9}$ However, between 1979 and 1987, the credit was treated as income. Since 1988 (the main period of importance), the EITC once again is not counted as income.

\subsubsection{The EITC Reforms}

The trends presented in section 10.2 show the quite dramatic increases in employment among single women with children in the United States. The explanations advanced in the literature include the expansion of the EITC, increases in the minimum wage, welfare reform, and the sustained economic expansion. Of particular interest here is the role played by the EITC. An expansion in the EITC leads unambiguously to increases in employment rates for single women with children. The EITC policy reforms in 1986, 1990, and 1993 are useful in providing a before-and-after assessment of their effectiveness in changing labor market behavior. Eissa and Liebman (1996) use repeated cross sections of the Current Population Survey (CPS) to examine the effect of the 1986 reform on single mothers. They consider two comparisons: either the whole group of single women with children is used, with single women without children as controls, or the group of low-education single women with children is used, with the loweducation single women without children as controls. The former control group can be criticized for not capturing the common macro effects. In particular, this control group is already working at a very high level of participation in the U.S. labor market (around 95 percent) and therefore cannot be expected to increase its level of participation in response to the economy's coming out of a recession. In this case all the expansion in labor market participation in the group of single women with children will be attributed to the reform itself. The latter group is therefore more appropriate as it targets better those single parents who are likely to be eligible for EITC, and the control group has a participation rate of about 70 percent.

With these caveats in mind, there remain some relatively strong results on participation effects that come from the Eissa and Liebman (1996) study. For single parents there is evidence of a reasonable movement in to work. The expansion of the EITC and other tax changes led to a reduction in the relative tax liability of single mothers of $\$ 1,331$ (1996 dollars), and their estimated impact of the expansion was to increase employment from

9. Although the EITC was counted as income for 1979-1987, when it counted as income changed somewhat. For part of the period, the credit only counted as income in the month that it was received (remember that the vast majority of recipients receive it as a tax refund in one annual payment), whereas in another part of this period, the imputed value of the credit was spread out over the year. 


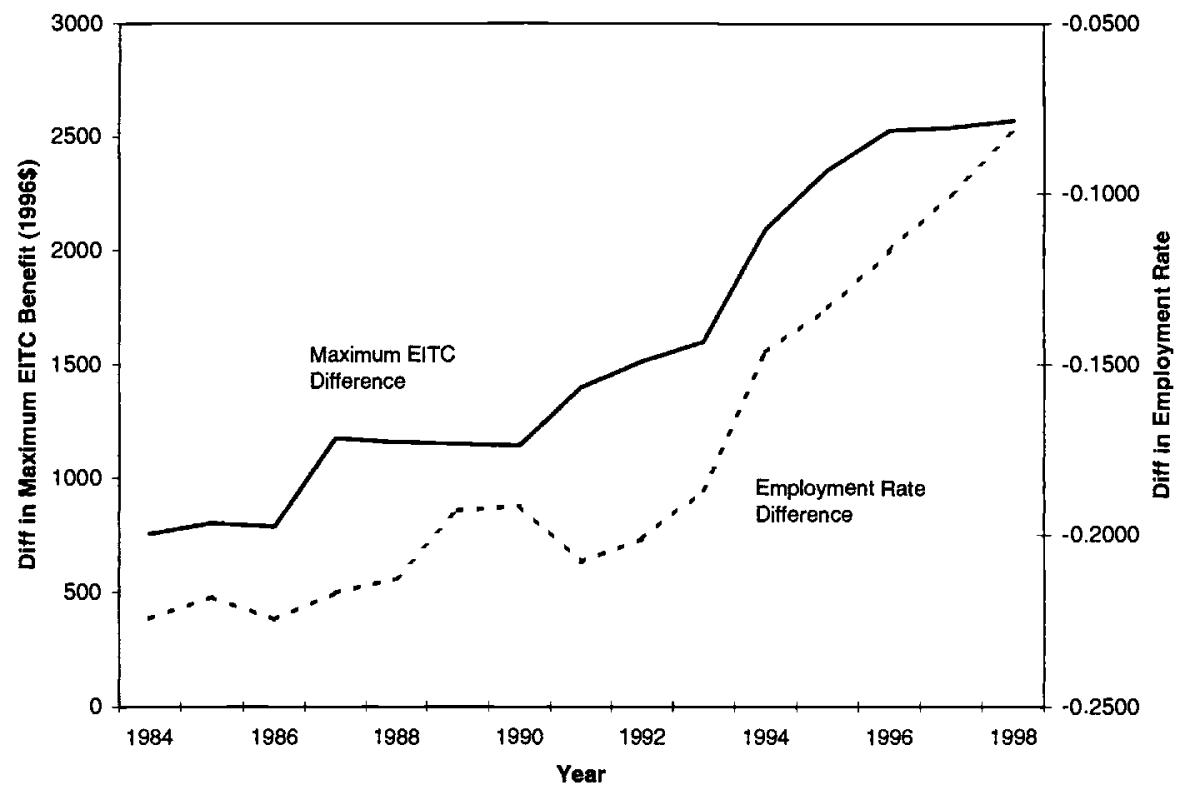

Fig. 10.17 Maximum EITC and difference in annual employment rates (comparison: single women with children to single women without children)

Source: Liebman (1998) figure 6.

Notes: Updated through 1998 using unpublished data from Liebman. The employment rate figure is based on a CPS sample of single women aged sixteen-forty-five who are not disabled or in school. Employment rate difference is the difference between the annual employment rate of single women with children and the annual employment rate of single women without children.

73.0 to 75.8 percent. There is also some evidence of negative effect on hours for those in work, but this is rather small.

Liebman (1998) and Meyer and Rosenbaum (2000) use a similar approach to examine the impact of all three of the EITC reforms. The estimated behavioral responses are very similar in magnitude to those found by Eissa and Liebman (1996). The Liebman results are summarized in figure 10.17. The figure plots the difference in employment rates of single women with and without children against the difference in the maximum EITC credit in 1996 dollars. ${ }^{10}$ The figure shows that the relative increase in employment rates among single mothers tracks quite closely the expansion of the EITC. Meyer and Rosenbaum (2000) present similar calculations for several other comparison groups, including comparing single women with

10. In the early period, the difference in maximum credit is equal to the credit for families with children. Figure 10.17 takes into account that there was a small EITC for childless families starting in 1994. It is not clear whether Liebman (1998) took this into account in his calculation. 


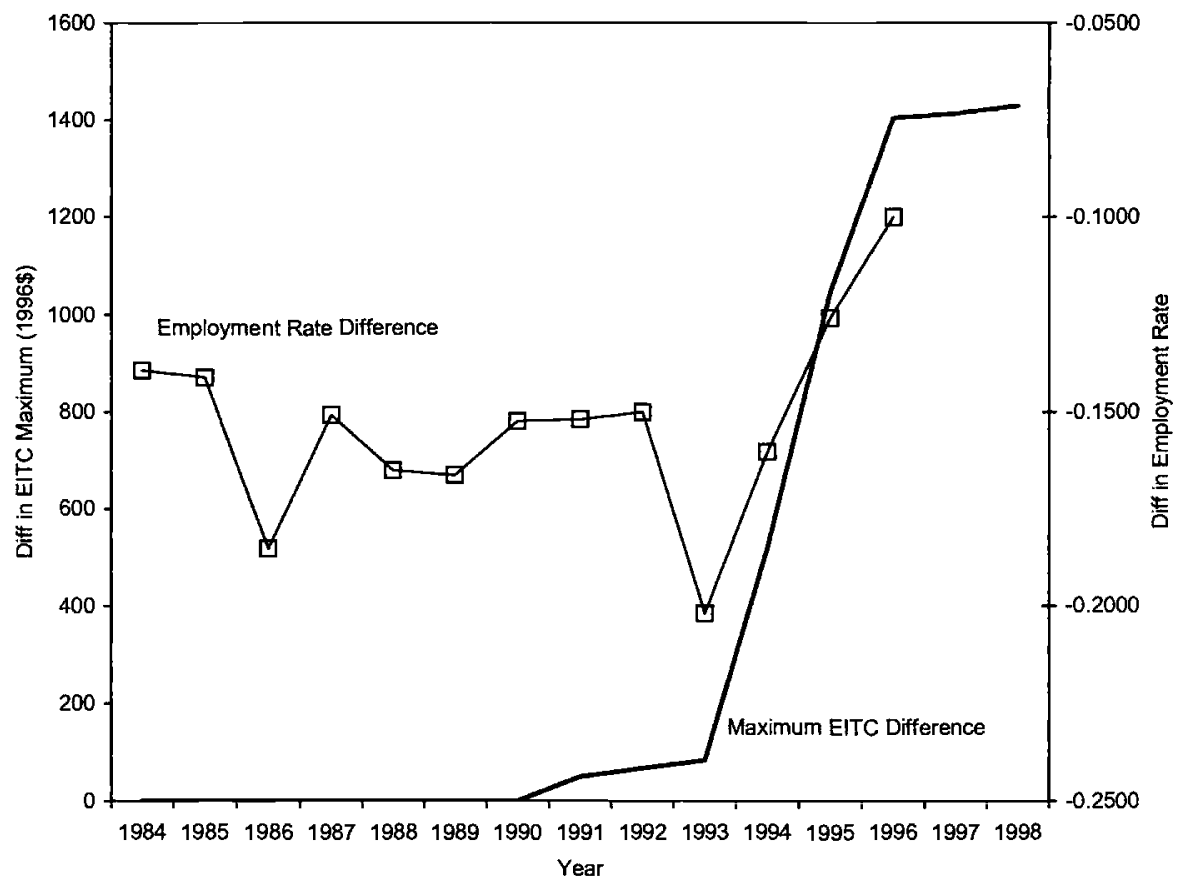

Fig. 10.18 Maximum EITC and difference in annual employment rates (comparison: single women with one child to single women with two-plus children)

Source: Employment rate differences come from table 6 in Meyer and Rosenbaum (2000).

Notes: Employment rate differences use a CPS sample of single women aged nineteen-fortyfour who are not disabled or in school. Employment rate difference is the difference between the annual employment rate of single women with two or more children and the annual employment rate of single women with one child.

one child to those with two or more children, single mothers to married mothers, and single mothers to black men. Figure 10.18 summarizes the results comparing single women with one child to those with two or more children. The "treatment" here is that the 1993 EITC expansion was much more generous for families with two or more children. These results are somewhat less clear than those discussed previously but show an increase in employment of single women with two or more children relative to those with only one child at the same time that the EITC is becoming more generous for larger families. ${ }^{11}$

Of course, the EITC reforms were not the only changes affecting the returns to work during this period. As recently discussed by Blank (2001),

11. The employment figures in Liebman (1998) and Meyer and Rosenbaum (2000) are unconditional. The authors state that the general conclusions do not change when adding controls. 
the mid-1990s simultaneously brought EITC expansions, minimum-wage increases, welfare reform, and the very strong labor market. ${ }^{12}$ Blank argues that our ability to determine the relative importance of these factors is limited by the fact that the changes were coincident. Despite these difficulties, Meyer and Rosenbaum (2001) examine the determinants of employment of single mothers between 1984 and 1996. This period ends before federal welfare reform but includes the period when states were experimenting with welfare waivers. They use a sample of single mothers with and without children and model the gains to entering work for the two groups, taking into account a rich set of tax and transfer programs. They find that expansions in the EITC account for 60 percent of the sizeable increase in employment rates, with smaller impacts due to welfare waivers and declining real welfare benefits. Ellwood (2000), comparing employment across skill groups, also finds changes to welfare and the EITC to have stimulated the labor supply of single mothers with children. However, in contrast to Meyer and Rosenbaum (2001), his work finds that welfare program changes were slightly more important than the EITC expansions.

Overall, the literature suggests that the EITC has played an important role in the large increases in employment among single women with children. Eissa and Hoynes (2004) is one of the few papers that have considered the impact of the EITC on married couples. They use two estimation approaches. In the first, they compare the labor market outcomes of married couples with children to married couples without children. In the second, they limit the sample of married couples with children and model changes in the returns to work, including tax and transfer policy changes. Using both methods, they find that an expansion in the EITC leads to modest increases in labor force participation for married men and somewhat larger decreases in labor supply for married women. That is, they find evidence of a negative "income" effect reducing the labor supply of married women. This is precisely the adverse effect that can be expected when a work-contingent tax credit is based on a family income and will also be found in our evaluation of the likely impact of the WFTC in the United Kingdom. ${ }^{13}$

\subsection{Evaluating the WFTC Reform}

As was described in section 10.3, the WFTC introduced in October 1999 is substantially more generous than the prior in-work benefit in the United Kingdom-FC. It increases the generosity of in-work support relative to the FC system in four ways: (1) by enhancing the credit for younger chil-

12. The federal minimum wage increased in nominal terms from $\$ 3.35$ in 1990 to $\$ 5.15$ in 1997.

13. This negative labor supply result for married couples can also be found in Dickert, Houser, and Scholz (1995) and Neumark and Wascher (2000). 
dren; (2) by increasing the threshold; (3) by reducing the benefit reduction rate from 70 percent to 55 percent; and (4) by incorporating a new child care credit of 70 percent of actual child care costs up to a quite generous limit. As we have argued, there are two important aspects of the U.K. benefit and credit system that have to be accounted for when assessing any inwork benefit reform. First, any increase in generosity will be dampened by interactions with means-tested income maintenance schemes, in particular, the Housing Benefit scheme. As we noted previously, four-fifths of single parents who do not work and who claim Income Support are in receipt of Housing Benefit. Second, increases in the credit for children and in the threshold level have been typically matched by increases to income support for nonworking parents. As our discussion in section 10.3 stressed, this has also been a feature of the WFTC reform.

\subsubsection{Simulating the Reform}

To provide an ex ante simulation of the impact of new reforms like the WFTC, a model is required that separates preferences from constraints. Such a model is developed in Blundell et al. (2000). This work develops earlier structural labor supply simulation models ${ }^{14}$ by Hoynes (1996), for example, and provides a similar framework to Bingley and Walker (1997) who considered earlier reforms to the U.K. benefit system. In particular, it allows for child care demands to vary with hours worked, and it allows for fixed costs of work. It also accounts for take-up by incorporating welfare stigma, following on from Keane and Moffitt (1998). ${ }^{15}$ This model was estimated and the simulations reported here computed before the WFTC was fully implemented.

The simulations focus on the two target groups for the WFTC reform: single parents and married couples with children. Two samples from the 1994-1995 and 1995-1996 British Family Resources Surveys (FRS) are selected: single-parent households and married or de facto married couples. Excluding self-employed and retired households, together with students and those in Her Majesty's forces, leaves samples of 1,807 single parents and 4,694 two-person households for use in estimation. Nearly 50 percent of currently working single parents were found to be in receipt of some FC. For married couples with children this proportion is smaller, at around 16 percent. However, the latter group is more than two and one-half times the size of the former.

14. Blundell and MaCurdy (1999) provide a detailed overview of such models.

15. Introducing a stigma cost to participation in WFTC allows the simulation model to predict a low probability of take-up among those with low eligibility - something found in earlier studies of welfare program take-up in the United Kingdom (Blundell and Fry 1986). Moreover, it suggests a higher take-up of WFTC (in contrast to FC) for those whose eligible amount of credit has increased as a result of the WFTC reform. 
As we have seen, the WFTC reform is designed to influence the work incentives of those with low potential returns in the labor market. It does this via the increased generosity of in-work means-tested benefits. For single parents, the WFTC does unambiguously increase the incentive to work. For couples, however, the incentives created by the WFTC can lead to lower participation in the labor market. This offsetting effect on employment for secondary workers in couples has also been highlighted in the context of the EITC reforms; see Eissa and Hoynes (2004) and the previous discussion.

Panel A of figure 10.19 shows the effect of the WFTC reform on the net income and hours schedule for a typical eligible single parent. This accounts for all the interactions in the tax and benefit system and concurrent reforms to the income support system. Provided that the fixed costs of work are not too high, the financial incentive to move into work for a nonparticipant is clear. There is also an incentive to reduce hours of work among those single parents working full time. The balance between these is purely an empirical matter, although the EITC analysis, discussed in the previous section, suggested that the adverse hours effect would not dominate the positive participation effect.

Panel C of figure 10.19 presents a similar example of the financial incentives facing a male in a married couple where the partner does not work. For such couples, where neither parent is working, the incentives are unambiguously to move into work. Indeed, the gains are far larger than for our lone parent example, as the largest cash gains from the WFTC reform accrue to those at the end of the current taper. The incentives to change hours of work are ambiguous. But one interesting point is the marked increase in the effective marginal tax rate for those who become eligible for WFTC as a result of the reform. This group faces an increase in the marginal tax rates, from 33 percent, produced by income tax and National Insurance, to just under 70 percent, produced by the interaction of the 55 percent WFTC taper on posttax income. In the example, the marginal tax rate rises from 33 percent to just under 70 percent above forty hours of work.

One final point, highlighted in our discussion of the EITC reforms in the United States, is the likely incentive for some workers in married couples to move out of work altogether. Panel D of figure 10.19 shows the budget constraint for the partner of the man in panel $\mathrm{C}$ of figure 10.19. The panel is conditional on the man working forty hours a week. Thus the family income of the woman when she does not work is that shown at the forty-hour point. This means that the income at zero hours has increased through the WFTC reform. In the example, anyone working more than ten hours has an increased incentive to reduce their hours or move out of work altogether. The situation changes slightly when we allow for child care costs at sixteen hours as shown in panel $\mathrm{E}$ of figure 10.19. Here there is an additional 


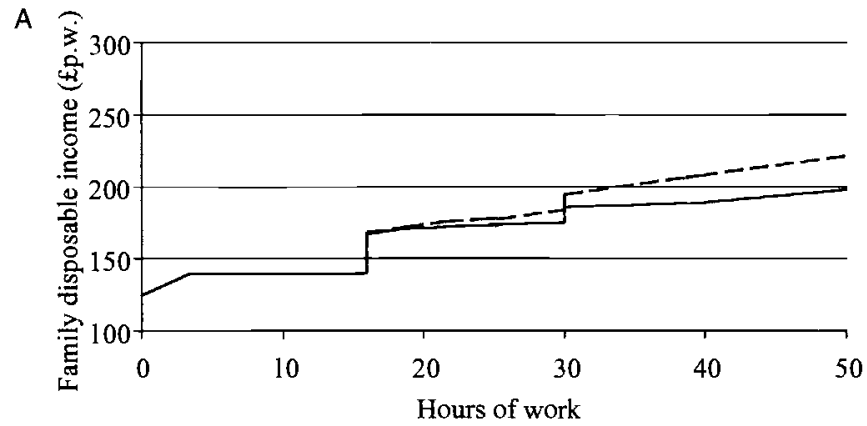

- WFTC — Family Credit

B

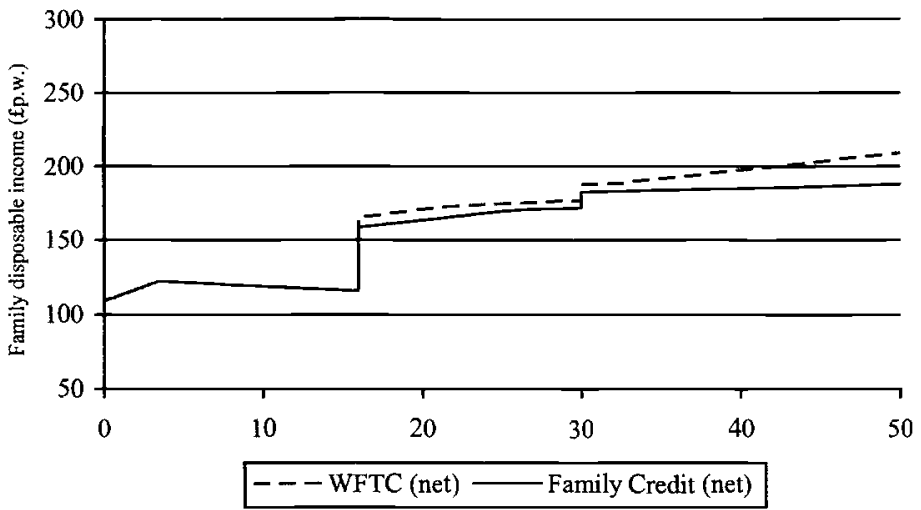

Fig. 10.19 WFTC reform budget constraints: $A$, lone parent without child care; $B$, lone parent with child care; $C$, man in couple without child care; $D$, woman in couple without child care; $E$, woman in couple with child care

Notes: $A$, One child aged under eleven; hourly wage $£ 4.39$ (median for lone parents); rent $£ 41.10$ per week (median for social renters with children); no child care costs; $B$, one child aged under eleven; hourly wage $£ 4.39$ (median for lone parents); rent $£ 41.10$ per week (median for social renters with children); child care at $£ 1.96$ per hour; $C$, spouse not working; one child aged under eleven; hourly wage $£ 5.87$ ( 25 th percentile for men in couples with children); rent $£ 41.10$ per week (median for social renters with children); $D$, spouse working forty hours at $£ 5.87$ per hour; one child aged under eleven; hourly wage $£ 3.72$ ( 25 th percentile for women in couples with children); rent $£ 41.10$ per week (median for social renters with children); no child care costs; $E$, spouse working forty hours at $£ 5.87$ per hour; one child aged under eleven; hourly wage $£ 3.72$ ( 25 th percentile for women in couples with children); rent $£ 41.10$ per week (median for social renters with children). 

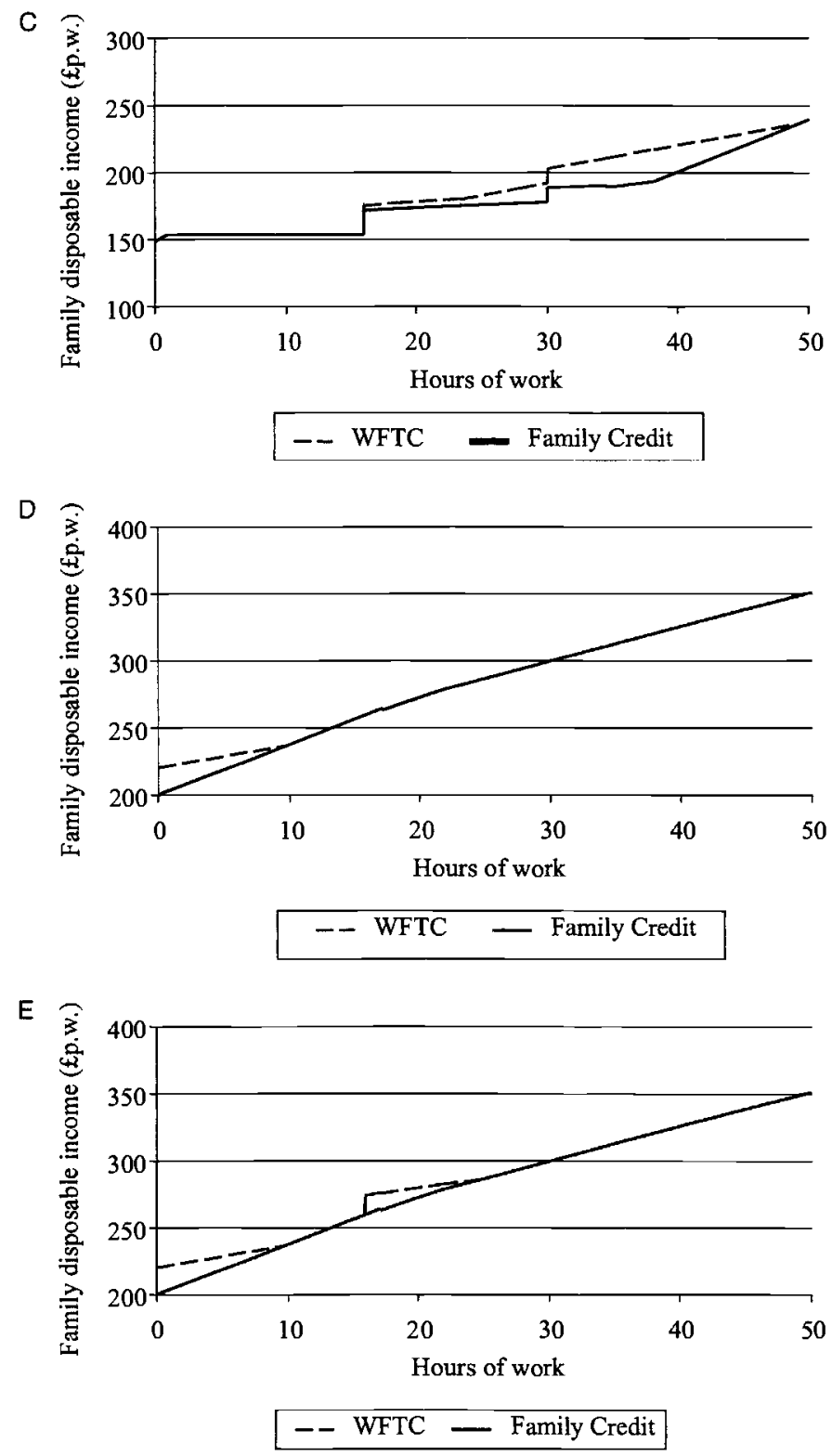

Fig. 10.19 (cont.) 
incentive to work just over sixteen hours to take advantage of the child care credit. Thus, the impact on partners in eligible families where there is already one worker is again ambiguous.

\section{WFTC Simulations: Lone Parents}

In the first section of table 10.4 the simulated work responses to the WFTC among the sample of single parents are reported. The simulated transition takes around 2.2 percent of the sample from no work to either part-time or full-time work, with no offsetting movements out of the labor market. This represents nearly a 5 percent impact on employment for this group, which has employment rates around 40 percent. To take account of sampling variability, a standard error of 0.42 percent is placed around the 2.2 percent figure.

Table 10.4

Working Families Tax Credit Reforms, Simulations

\begin{tabular}{|c|c|c|c|c|}
\hline \multirow[b]{2}{*}{ Prereform } & \multicolumn{3}{|c|}{ Postreform } & \multirow[b]{2}{*}{ Prereform $(\%)$} \\
\hline & Out of Work & Part-Time & Full-Time & \\
\hline \multicolumn{5}{|c|}{ Single Parents } \\
\hline Out of work & 58.0 & 0.7 & 1.5 & 60.2 \\
\hline Part-time & 0.0 & 18.6 & 0.5 & 19.1 \\
\hline Full-time & 0.0 & 0.2 & 20.6 & 20.7 \\
\hline Postreform $(\%)$ & 58.0 & 19.4 & 22.6 & 100 \\
\hline Change $(\%)$ & -2.2 & 0.3 & 1.9 & \\
\hline \multicolumn{5}{|c|}{ Married Women with Employed Partners } \\
\hline Out of work & 32.2 & 0.1 & 0.1 & 32.4 \\
\hline Part-time & 0.3 & 31.6 & 0.0 & 32.0 \\
\hline Full-time & 0.4 & 0.1 & 35.0 & 35.6 \\
\hline Postreform (\%) & 33.0 & 31.8 & 35.2 & 100 \\
\hline Change $(\%)$ & 0.6 & -0.1 & -0.4 & \\
\hline \multicolumn{5}{|c|}{ Married Women with Partners Out of Work } \\
\hline Out of work & 56.8 & 0.4 & 0.9 & 58.1 \\
\hline Part-time & 0.0 & 22.2 & 0.4 & 22.6 \\
\hline Full-time & 0.0 & 0.1 & 19.2 & 19.3 \\
\hline Postreform $(\%)$ & 56.8 & 22.8 & 20.5 & 100 \\
\hline Change $(\%)$ & -1.3 & 0.2 & 1.1 & \\
\hline Group & & \multicolumn{2}{|c|}{ Number } & \\
\hline \multicolumn{2}{|c|}{ Single parents } & \multicolumn{2}{|c|}{34,000} & \\
\hline \multirow{2}{*}{\multicolumn{2}{|c|}{$\begin{array}{l}\text { Married women (partner not working) } \\
\text { Married women (partner working) }\end{array}$}} & \multicolumn{2}{|c|}{11,000} & \\
\hline & & $-20,000$ & \multicolumn{2}{|c|}{-0.57} \\
\hline \multicolumn{2}{|c|}{$\begin{array}{l}\text { Married women (partner working) } \\
\text { Married men, partner not working }\end{array}$} & \multicolumn{2}{|c|}{13,000} & 0.37 \\
\hline \multicolumn{2}{|c|}{ Married men, partner working } & \multicolumn{2}{|c|}{$-10,500$} & \\
\hline \multicolumn{2}{|c|}{ Total effect } & \multicolumn{2}{|c|}{27,500} & \\
\hline \multicolumn{2}{|c|}{ Decrease in workerless families } & 57 & & \\
\hline
\end{tabular}

Source: Blundell, Duncan, McCrae, and Meghir (2000) and Blundell and Reed (2000). 


\begin{tabular}{lc}
\hline Group & Number in Population (thousands) \\
\hline Lone parents & \\
Total population & 1,600 \\
Modeled population & 1,550 \\
Couples: man working & \\
Total population & 4,550 \\
Modeled population & 3,500 \\
Couples: man not working & \\
Total population & 850 \\
Modeled population & 820 \\
\hline
\end{tabular}

Source: Department of Work and Pensions (1996).

To provide the population counterparts to these changes, table 10.5 provides the total size of the population and the grossed-up equivalent from the FRS sample. One can clearly see the reason for this shift in the earlier graphs of the potential impact of the WFTC on single parents' budget constraints. At or above sixteen hours per week, the single parent becomes eligible for WFTC (with any child care credit addition to which she may be entitled). For some women this extra income makes a transition to parttime employment attractive.

We see a minor offsetting reduction in labor supply through a simulated shift from full-time to part-time employment among 0.2 percent of the sample. This is consistent with a small (negative) income effect among some full-time single women, for whom the increase in income through the WFTC encourages a reduction in labor supply. Nevertheless, the predominant incentive effect among single parents is a positive effect on participation.

\section{WFTC Simulations: Women with Employed Partners}

For married women the simulated incentive effect is quite different. The second section of table 10.4 reports estimates of the transitions following WFTC among a subsample of women with employed partners. There is a significant overall reduction in the number of women in work of around 0.57 percent. This overall reduction comprises around 0.2 percent who move into the labor market following the reform, and 0.8 percent who move from work to nonparticipation. The number of hours worked by women with employed partners is predicted to fall slightly.

The predominant negative response is clearly not one that is intended, but from the earlier budget constraint analysis one can easily see why. There will be a proportion of nonworking women whose low-earning partners will be eligible for the WFTC. The greater generosity of the tax credit relative to the current system of FC increases household income. This in- 
crease in income would be lost if the woman in the household were to work. And for those women currently in the labor market, the WFTC increases the income available to the household if she were to stop working.

\section{WFTC Simulations: Women with Unemployed Partners}

In the third section of table 10.4 the incentives for a subsample of women whose partners do not work are presented. For this group there is a significant overall increase of 1.32 percent in the number of women who work. The reason for this shift is more straightforward and stems from the increased generosity of the basic WFTC relative to the current FC system for those women who choose to move into work. Note that for this group the generosity of the child care credit component of the WFTC is not an issue, because households only qualify for the child care credit if both household members work sixteen hours or more. There is, of course, potential for both members of an unemployed household to move into work in order to qualify for the WFTC that includes the child care credit, but a joint simulation (not reported here) shows that such an outcome is virtually nonexistent.

\section{WFTC Simulations: A Summary}

The fourth section of table 10.4 provides an overall summary of the employment effects that could be expected from this reform. This table also provides the impact on male employment. The impact on single parents is quite significant. This is also the case for workless couples with children. These are the two target groups we mentioned at the outset. However, "adverse" effects on couples in which one spouse is working somewhat offset these effects. Overall the effects on participation across the two groups of men roughly cancel out, leaving the major impact operating through the effects on women, mainly single parents. However, if we consider the impact on workless households alone, then the overall impact of the WFTC is predicted to be much more substantial.

\subsubsection{The WFTC Reform-Some Ex Post Evidence}

The WFTC was introduced for all new recipients in October 1999 and fully phased in by April 2000. From recent administrative caseload data (Department of Social Security [various years]), the introduction of the WFTC and the substantial increase in generosity appear to have had a marked effect on the number of people claiming in-work benefits. Figure 10.20 shows that caseload has risen by 30 percent in the twelve months since May 1999. Table 10.4 shows that the average award has risen from $£ 63$ to $£ 76$ a week over the same period. Average gross weekly income of claimants is now $£ 153$, and average weekly hours worked are 30.5 . Fifty-two percent of recipients are lone parents.

There has also been a large increase in take-up of the Childcare Tax 


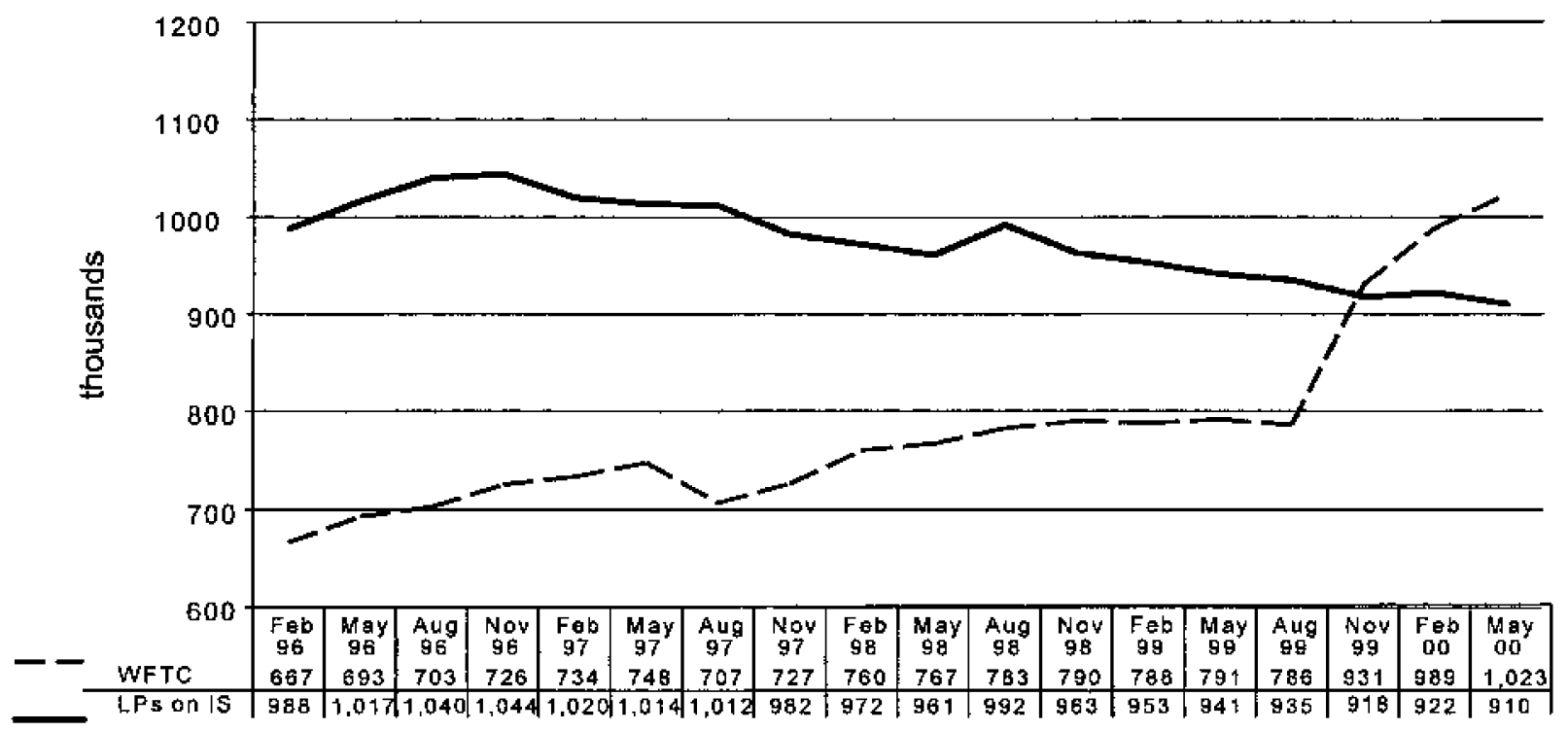

Fig. 10.20 Caseload of lone parents on lncome Support and all fanilies on FC and WFTC, 1996-2000

Serurce: Blundell (2002).

Note: Great Britain only. 
Credit compared to the child care disregard under FC. In May 2000111,000 families were receiving help with child care costs, a 156 percent increase over twelve months. The average amount of costs claimed was $£ 32$ a week. Although this is a large increase, however, this is still only 10 percent of the total WFTC caseload (table 10.5).

Obviously some of the change in WFTC caseload is due to the increased numbers of already working parents who qualify for WFTC due to its increased generosity. This alone cannot be taken as a measure of success in increasing employment. We can learn a little more by looking at administrative data on cross-benefit flows. Figure 10.21 breaks down the WFTC and FC caseload by their situation twelve months ago. It shows that a large component of the caseload increase (around 75 percent, taking the last four quarters of $\mathrm{FC}$ as a baseline) since October 1999 has come from people who were not claiming any means-tested benefits or tax credits twelve months before. Both of these facts are consistent with the increased entitlement of the WFTC compared with FC.

It is informative to compare the predicted labor supply effects discussed earlier with the available administrative data. The simulations reported in table $10.4^{16}$ estimate that around 30,000 currently workless lone parents with children will enter work as a result of WFTC. ${ }^{17}$ The government's equivalent (and unpublished) estimate for the package of tax and benefit reforms is around 40,000 lone parents with children. Although we cannot make accurate inferences from this high-level analysis of administrative data, we cannot yet see a change of this magnitude in the behavior of lone parents. When we compare February 2000 with August 1999, only 5 percent (10,000 families) of the increase in the WFTC and FC caseload is due to lone parents' moving from Income Support to WFTC.

There are several important reasons that could explain the discrepancy. First, responses to reforms take time. It took two years for the strong peak at sixteen hours to appear after the 1992 reform to FC in the United Kingdom. Second, we have presented an extremely crude analysis that does not, for example, control for any underlying changes in the number of lone parents moving from Income Support to WFTC and FC (for example, the number of lone parents moving from Income Support to WFTC and FC fell by 7,000 in the twelve months prior to August 1999). Third, we also cannot identify lone parents on other out-of-work benefits.

Nonetheless, taken together with our simulation results, these administrative statistics suggest that the impact of the WFTC reform on employment among low-income families in the United Kingdom is positive but modest. This supports our overall view that the workings of the tax and

16. Similar percentage effects on single parents can be found in the Gregg, Johnson, and Reed (1999) study.

17. We cannot analyze couples who move into work because of the difficulties in classifying couples who change claimants when they change benefits and tax credits. 


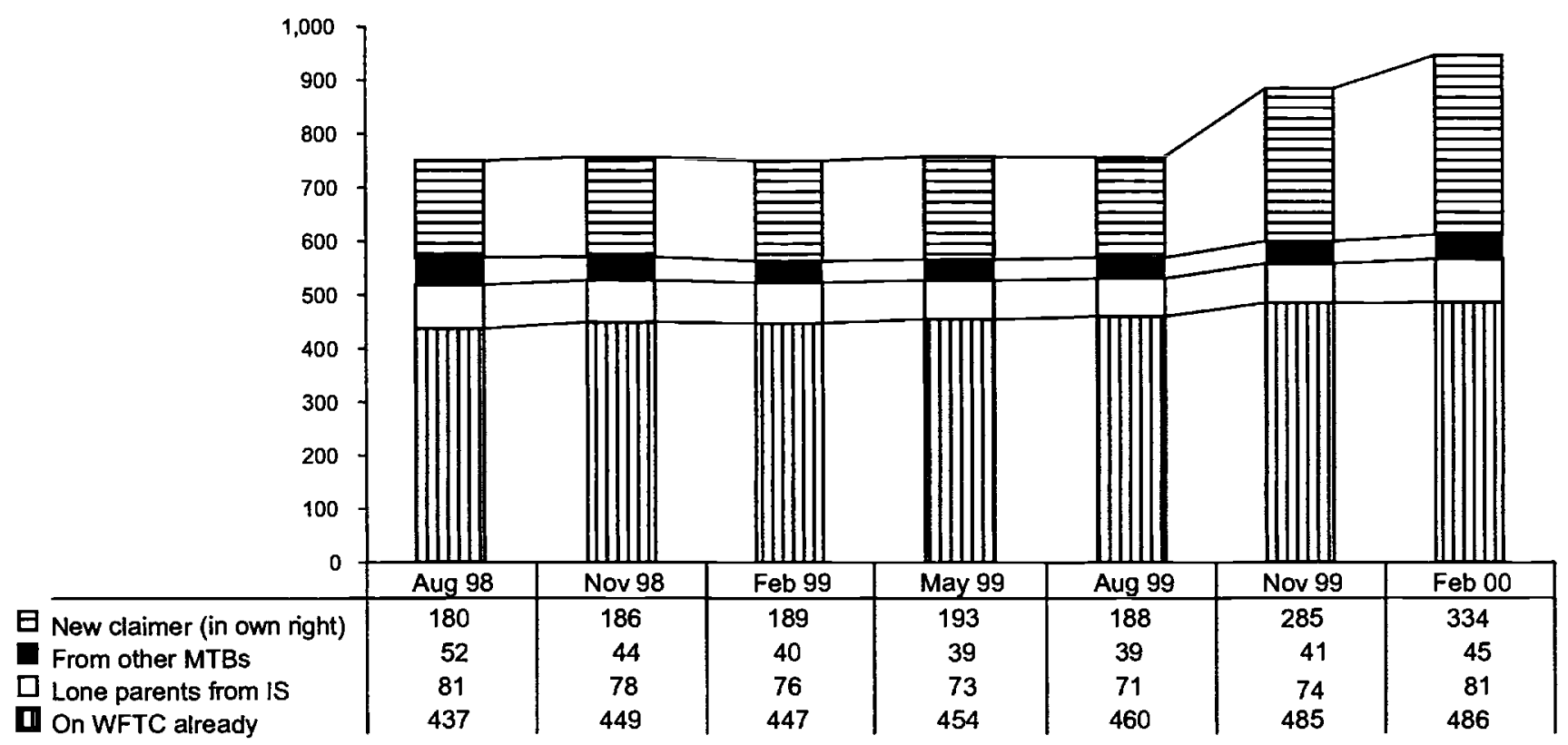

Fig. 10.21 Families on WFTC: Where were they twelve months ago?

Source: Blundell (2002). 
benefit system in the United Kingdom, together with the increased generosity to workless families with children, mean that changes to financial work incentives from in-work benefit reforms are relatively small.

One caveat to this is the possible impact of the child care credit. Under WFTC this is a generous scheme available only to those in work (requiring both parents in a couple to work at least sixteen hours), but, as we have indicated, it is currently taken up by only a small fraction of WFTC recipients. If participation in this part of the WFTC program was to expand significantly, it could further encourage labor supply among those low-income parents who are currently out of work and claiming Income Support.

\subsection{Summary and Conclusions}

The late 1980s and 1990s saw substantial expansions to the U.K. system of in-work benefits. Most recently, in 1999 the FC was expanded and replaced by the WFTC. The goal of these policy reforms was clear: to significantly increase the employment of the targeted groups of lone parents and workless couples. However, employment rates of single women with children, which declined dramatically with the recession of the early 1980s, have remained low relative to other groups. The United States also expanded its main in-work benefit program, the EITC, during the late 1980s and 1990s. But the U.S. expansions were accompanied by much larger increases in the employment rates of single mothers and heralded as a great policy success. The goal of our paper has been to explore this puzzle and determine why the results were different in the United Kingdom.

Our analysis leads to two key explanations. First, in-work benefits incentives in the United Kingdom are dulled by integration with the rest of the tax and benefit system. Second, in the United States, the expansions to the inwork benefits occurred at a time when the out-of-work benefits were being reduced. There was no corresponding reduction in the United Kingdom.

In relation to the first explanation, we point to the significant benefit reduction rate in the Housing Benefit program, inducing only small gains to working for those with large Housing Benefit entitlements. Many nonworking low-income families in the United Kingdom are in this position. In the United States, by contrast, the EITC is not counted as income for the calculation of any other transfer program, so the household sees the full gain of the in-work benefit. The interaction between in-work benefits and other means-tested benefits is of central importance in understanding the precise change in incentives that reforms to the in-work benefit system have delivered.

In terms of the second explanation, welfare programs in the United States underwent major reforms, leading to a decline in the value of staying out of the labor force for single mothers. Thus the increase in incentives to work through the EITC was strengthened by the decline in the generosity of out-of-work benefits. In the United Kingdom, by contrast, the out- 
of-work programs either maintained levels of generosity or, in some cases, actually increased generosity in step with the increases in the in-work programs. The combination of these two forces meant that the expansions of the U.K. in-work programs generated rather modest increases in the incentives to work.

It is not that we find no positive employment responses to the reforms in the United Kingdom. Indeed, there is strong evidence that certain targeted groups responded to the incentives in their labor supply behavior. For example, our simulations point to an important impact on single parents, drawing more than 30,000 into work and off income support from the recent WFTC reform. Also, we find a significant percentage of men and women in workless couples move into employment. However, these positive increases in employment for workless couples with children are offset somewhat by a decrease in the level of employment in couples with children where both spouses are working, reflecting the income effect. The reduction in workless families is therefore much more substantial than the increase in employment.

This can only be a partial assessment of the recent reforms to the structure of in-work benefits in the United Kingdom. There are several additional issues that have been raised. The first relates to child care. The recent reform in the United Kingdom contains a generous child care component. If taken up it could significantly improve the labor supply of the target groups. Also, it mitigates the offsetting effect on working married couples because there is a requirement that both parents work in a couple for eligibility. On face value, child care should be important. The data show that the low attachment rates are concentrated among women whose youngest child is below formal school age. Indeed, one interpretation of the experimental findings in Card and Robins (1998) is that in-work benefits speed up the entry into work of mothers with young children. However, to date, the take-up among couples is less than 2 percent, and among single parents it is less than 12 percent. These low take-up rates are something of a puzzle and may reflect the time taken for the child care market to adapt.

Finally, there is the issue of earnings progression. Will the earnings of the recipients who are brought into work due to the increased generosity of inwork benefit programs see any significant growth in real wages? Will they eventually be able to earn their way out of the in-work benefit system? How does a tax credit affect incentives for wage progression? Unlike the Canadian Self Sufficiency Project (SSP) experiment, the U.K. and U.S. systems are not time limited. At first sight, this looks to set up the wrong incentives for wage progression. Certainly the incentives for individuals to seek out wage progression are probably reduced. But, as pointed out by Heckman, Lochner, and Cossa (2002), distinguishing between the method of skill formation is key. Evidence on wage progression for these types of workers is sparse, but there are three important and relevant studies-the Card and Robins (1999) study of the wages of the control and treatment groups in the 
Canadian experiment, the Heckman, Lochner, and Cossa (2002) study of the impact of EITC on skill formation, and the Gladden and Taber (2000) study of true experience effects across education and gender groups in the United States. All of these studies point to modest wage growth. The first study suggests those drawn into the program do not experience significantly lower wage growth, although the level of wage growth is low. The second study highlights the importance of distinguishing between the method of skill formation - that is, whether it is dominated by on-the-job learning or learning by doing. The third study shows that, although growth is slow, it is rather similar across skill and gender groups. Positive news? Yes, but the rates of wage progression are small, and the wage levels of these individuals in the United Kingdom are very low. In Blundell (2002) it is argued that given the large impact on incomes-and implicitly on hourly wages - that is brought about through in-work benefits, it is doubtful that wage progression alone will lead to any significant movement out of inwork benefit receipt.

\section{Appendix}

\section{Data}

\section{U.K. Labor Market Sources and Definitions}

\section{Family Expenditure Survey (FES)}

The FES is a repeated continuous cross-sectional survey of households that provides consistent data on wages, hours of work, employment status in last two weeks, and education for each year since 1978. Family Expenditure Survey years correspond to the financial year. Consequently, 1998, for example, covers the twelve months up to April 1999. It therefore corresponds to 1999 in the March CPS data used in the U.S. comparisons. Prior to 1978 the FES contains no information on educational attainment. In particular, the survey contains information on usual labor market status.

\section{Low Education}

We show trends for all women and trends in a low-education sample classified as those who left full-time education at age sixteen or lower. An alternative to our method for constructing the education dummy would use those who left education at the statutory minimum age as the base group. This method is equivalent to ours from 1973 onward in the United Kingdom; before this date the minimum school-leaving age was a year lower, at fifteen. Nonetheless, interactions between date-of-birth cohort effects and the education dummy will capture any effects of the change in 
minimum leaving age on the relative returns to education enjoyed by the seventeen-plus group. See Gosling, Machin, and Meghir (2000). We use this criterion to better select women affected by the in-work benefit reforms under consideration.

\section{Labour Force Survey (LFS)}

The LFS is a quarterly survey of some 60,000 working-age individuals in the United Kingdom.

\section{Family Resources Survey (FRS)}

The FRS is a continuous survey with an annual sample size of around 25,000 private households. It provides detailed income and benefit data for individuals in households and is representative of the whole population.

\section{U.S. Labor Market Sources and Definitions}

\section{The March Current Population Surveys (CPS)}

The March CPS is an annual demographic file of between 50,000 and 62,000 households. For each individual in the household the survey provides detailed information on labor market, income, and demographic characteristics. In particular, the survey contains information on labor market status of the last week as well as detailed labor market information for the previous calendar year. Our main labor market measure from the CPS is work status of the last week, but as an alternative measure we consider weeks worked in the last year. As for the United Kingdom, we calculate trends in these labor market variables using women between the ages of twenty and fifty-four. We also restrict the sample in this way because we do not want to address issues of early retirement and exit from the labor market. We present trends in labor market variables by marital status and presence of children.

\section{Low Education}

The low education sample consists of women with no more than a high school education (less than or equal to twelve years of education). Again, we use this criterion to better select women affected by the EITC.

\section{References}

Bingley, P., and I. Walker. 1997. The labour supply, unemployment and participation of lone mothers in in-work transfer programs. Economic Journal 107:1375390 . 
Blank, R. M. 2001. Declining caseloads/increased work: What can we conclude about the effects of welfare reform. Economic Policy Review 7:25-36.

Blundell, R. W. 2000. Work incentives and in-work benefit reforms: A review. $O x-$ ford Review of Economic Policy 16 (1): 27-44.

Blundell, R. W. 2001. Welfare reform for low income workers. Oxford Economic Papers 53:189-214.

Blundell, R. W. 2002. Welfare to work: Which policies work and why? Keynes Lecture in Economics 2001. In Proceedings of the British Academy 117 (November): 477-524. London: The British Academy.

Blundell, R. W., A. S. Duncan, J. McCrae, and C. Meghir. 2000. The labour market impact of the Working Families Tax Credit. Fiscal Studies 21:65-74.

Blundell, R. W., and V. Fry. 1986. Modeling the take-up of means tested benefits: The case of housing benefits in the UK. Economic Journal 83:18-34.

Blundell, R. W., and T. MaCurdy. 1999. Labor supply: A review of alternative approaches. In Handbook of labor economics, vol. 3, ed. O. Ashenfelter and D. Card, 1559-695. Amsterdam: Elsevier/North-Holland.

Blundell, R. W., and C. Meghir. 2002. Active labour market policy vs. employment tax credits: Lessons from recent UK reforms. Swedish Economic Policy Review 8 (January): 13-37.

Blundell, R. W., and H. Reed. 2000. The employment effects of the Working Families Tax Credit. IFS Briefing Note no. 6. London: Institute for Fiscal Studies, April.

Brewer, M. 2000. Comparing in-work benefits and financial work incentives for low-income families in the US and the UK. Institute for Fiscal Studies Working Paper no. W00/16, Fiscal Studies, forthcoming.

Brewer, M., M. Myck, and H. Reed. 2001. Financial support for families with children. IFS Commentary no. 82. London: Institute for Fiscal Studies, January.

Card, D., and K. Robins. 1998. Do financial incentives encourage welfare recipients to work? Research in Labor Economics 17:1-56.

. 1999. Measuring "wage progression" among former welfare recipients. Center for Labor Economics Discussion Paper no. 20. Berkeley: University of California.

Department of Social Security. Various years. Client group analysis-Working age. London: Government Statistical Service.

Department of Work and Pensions. 1996. Family Resources Survey, 1994-1995. London: Her Majesty's Stationery Office.

Dickert, S., S. Houser, and J. K. Scholz. 1995. The Earned Income Tax Credit and transfer program: A study of labor market and program participation. In Tax policy and the economy, vol. 9, ed. J. M. Poterba, 1-50. Cambridge: MIT Press.

Dilnot, A., J. Kay, and C. Morris. 1984. The reform of Social Security. Oxford: Oxford University Press.

Dilnot, A., and I. Walker, eds. (1992). The economics of Social Security. Oxford: Oxford University Press.

Duncan, A., and C. Giles. 1996. Labour supply incentives and recent family credit reforms. Economic Journal 106:142-155.

Eissa, N., and H. W. Hoynes. 2004. Taxes and the labor market participation of married couples: The Earned Income Tax Credit. Journal of Public Economics forthcoming.

Eissa, N., and J. B. Liebman. 1996. Labor supply response to the Earned Income Tax Credit. Quarterly Journal of Economics 111:605-637.

Ellwood, D. T. 2000. The impact of EITC and other social programs on work and marriage in the United States. National Tax Journal 53 (4): 1063-106. 
Giles, C., P. Johnson, and J. McCrae. 1997. Housing benefit and the financial returns to employment for tenants in the social sector. Fiscal Studies 18:49-72.

Gladden, T., and C. Taber. 2000. Wage progression among less skilled workers. In Finding jobs: Work and welfare reform, ed. D. Card and R. M. Blank, 160-192. New York: Russell Sage Foundation.

Gosling, A., S. Machin, and C. Meghir. 2000. The changing distribution of male wages in the U.K. Review of Economic Studies 67 (4): 635-666.

Gregg, P., P. Johnson, and H. Reed. 1999. Entering work and the British tax and benefit system. IFS Monograph. London: Institute for Fiscal Studies, March.

Heckman, J. J., L. Lochner, and R. Cossa. 2002. Learning-by-doing vs on-the-job training: Using variation induced by the Earned Income Tax Credit to distinguish between models of skill formation. University of Chicago. Working Paper.

Her Majesty's Treasury. 2000. Tackling poverty and making work pay: Tax credits for the 21 st century, The Modernisation of Britain's Tax and Benefit System Treasury Monograph no. 6. London: Her Majesty's Stationery Office.

Hoynes, H. W. 1996. Welfare transfers in two-parent families: Labor supply and welfare participation under the AFDC-UP Program. Econometrica 64 (2): 295 332.

Hoynes, H. W. 2000. The employment and earnings of less skilled workers over the business cycle. In Finding jobs: Work and welfare reform, ed. R. M. Blank and D. Card, 23-71. New York: Russell Sage Foundation.

Hoynes, H. W., and T. MaCurdy. 1994. Has the decline in benefits shortened welfare spells? American Economic Review 84 (2): 43-48.

Keane, M. P., and R. Moffitt. 1998. A structural model of multiple welfare program participation and labor supply. International Economic Review 39:553-589.

Liebman, J. B. 1998. The impact of the Earned Income Tax Credit on incentives and income distribution. In Tax policy and the economy, vol. 12, ed. J. M. Poterba, 83-119. Cambridge: MIT Press.

Meyer, B., and D. T. Rosenbaum. 2000. Making single mothers work: Recent tax and welfare policy and its effects. National Tax Journal 53 (4): 1027-062.

2001. Welfare, the Earned Income Tax Credit, and the labor supply of single mothers. Quarterly Journal of Economics 116 (3): 1063-114.

Neumark, D., and W. Wascher. 2000. Using the EITC to help poor families: New evidence and a comparison with the minimum wage. NBER Working Paper no. 7599. Cambridge, Mass.: National Bureau of Economic Research, March.

Schoeni, R., and R. M. Blank. 2000. What has welfare reform accomplished? Impacts on welfare participation, employment, income, poverty, and family structure. NBER Working Paper no. 7627. Cambridge, Mass.: National Bureau of Economic Research, March.

U.S. House of Representatives. 2000. Background materials and data on programs within the jurisdiction of the Committee on Ways and Means. Washington, D.C.: GPO. 
This Page Intentionally Left Blank 